\title{
Herordening van het sacrale : religie, ethiek en zorginnovatie
}

Citation for published version (APA):

Verkerk, M. J. (2010). Herordening van het sacrale : religie, ethiek en zorginnovatie. Maastricht University. https://doi.org/10.26481/spe.20100205mv

Document status and date:

Published: 05/02/2010

DOI:

10.26481/spe.20100205mv

Document Version:

Publisher's PDF, also known as Version of record

\section{Please check the document version of this publication:}

- A submitted manuscript is the version of the article upon submission and before peer-review. There can be important differences between the submitted version and the official published version of record.

People interested in the research are advised to contact the author for the final version of the publication, or visit the DOI to the publisher's website.

- The final author version and the galley proof are versions of the publication after peer review.

- The final published version features the final layout of the paper including the volume, issue and page numbers.

Link to publication

\footnotetext{
General rights rights.

- You may freely distribute the URL identifying the publication in the public portal. please follow below link for the End User Agreement:

www.umlib.nl/taverne-license

Take down policy

If you believe that this document breaches copyright please contact us at:

repository@maastrichtuniversity.nl

providing details and we will investigate your claim.
}

Copyright and moral rights for the publications made accessible in the public portal are retained by the authors and/or other copyright owners and it is a condition of accessing publications that users recognise and abide by the legal requirements associated with these

- Users may download and print one copy of any publication from the public portal for the purpose of private study or research.

- You may not further distribute the material or use it for any profit-making activity or commercial gain

If the publication is distributed under the terms of Article $25 \mathrm{fa}$ of the Dutch Copyright Act, indicated by the "Taverne" license above, 


\section{Maastricht University}

Prof. Dr. Maarten J. Verkerk

Faculty of Arts and Social Sciences

\section{Herordening van het sacrale Religie, ethiek en zorginnovatie}


Herordening van het sacrale Religie, ethiek en zorginnovatie 


\section{Colofon}

Ontwerp en print: Océ Business Services, Maastricht

ISBN: 978-90-5681-325-3

NUR: 705

Alle rechten voorbehouden. Niets uit deze uitgave mag worden verveelvoudigd, opgeslagen in een geautomatiseerd gegevensbestand of openbaar gemaakt worden, zonder voorafgaande schriftelijke toestemming van de auteur of uitgever. 


\section{Herordening van het sacrale Religie, ethiek en zorginnovatie}

Oratie

Maastricht, 5 februari 2010

Door Prof. Dr. Maarten J. Verkerk 
Herordening van het sacrale 
Mijnheer de Rector Magnificus, geachte toehoorders,

\section{Inleiding}

'Wat doet een calvinist aan een seculiere universiteit in het roomse Zuiden?' Deze vraag heb ik meerdere malen gekregen toen ik als bijzonder hoogleraar Reformatorische Wijsbegeerte aan deze universiteit werd benoemd. Alleen de formulering roept al vragen op. Deze suggereert het bestaan van verschillende werelden die elkaar nauwelijks raken: de sobere calvinistische traditie, de rationele seculiere wetenschap, en de rijke roomse cultuur. Het suggereert ook dat ik een verscheurd bestaan leid omdat het onmogelijk is tegelijkertijd in deze drie verschillende werelden te leven. Wat dat laatste betreft: het medeleven doet me goed, maar $u$ hoeft zich geen zorgen te maken.

De vraag 'Wat doet een calvinist aan een seculiere universiteit in het roomse Zuiden?'is mijns inziens typerend voor de tijd waarin we leven. We vinden het moeilijk om de relaties tussen cultuur, wetenschap en religie te duiden. Nog maar enkele decennia geleden was dat anders. De woorden 'verzuiling' en 'grote verhalen' herinneren ons aan een tijd waarin het vanzelfsprekend was dat de verschillende sectoren van het maatschappelijke leven met elkaar samenhingen en op een bepaalde manier met elkaar vervlochten waren. Deze vanzelfsprekendheid werd onderbouwd en gelegitimeerd vanuit de levensbeschouwing. De secularisatie is in Nederland zodanig voortgeschreden dat velen religie en ideologie niet van binnenuit kennen. Met als gevolg dat er schotten worden opgetrokken tussen de verschillende sectoren van het maatschappelijk leven.

Dit komt onder andere naar voren in de discussie over de rol van religie in de openbare ruimte. In de neoliberale visie is de openbare ruimte neutraal. Elke burger dient zich daar te onthouden van religieuze tekens, uitingen of argumenten. Religie mag alleen in de privésfeer beleefd worden. In beeldtaal: geloofsovertuigingen zijn kleine privé-eilandjes in een uitgestrekte seculiere zee. Op het eerste gezicht is dit neoliberale standpunt helder. Er gaat ook een zekere aantrekkingskracht van uit: in een neutrale openbare ruimte kunnen alle burgers toch tot hun recht komen? Maar wie dieper graaft, stuit op belangrijke filosofische vragen. Wat bedoelen we - in een democratische rechtsorde! - met 'neutraliteit'? Wat is precies die 'openbare ruimte'? En kan een politiek standpunt überhaupt neutraal zijn?' 
In onze samenleving is het niet vanzelfsprekend dat religie een rol speelt in het publieke debat en in de vormgeving van de samenleving. Zoals ik al aangaf: enkele decennia geleden was dat in Nederland nog anders. Maar ook in andere culturen is dat anders. Ik verwijs als voorbeeld naar het boek Het huis van de moskee van Kader Abdolah waarin hij laat zien hoe in Iran de werelden van cultuur, politiek en religie volledig met elkaar vervlochten zijn².

Hoe verhouden religie en samenleving zich tot elkaar? Wat is de relatie tussen het sacrale en het seculiere, tussen het heilige en het profane? In mijn oratie wil ik laten zien dat deze relatie bijzonder complex is en in de loop van de geschiedenis verschillende vormen heeft aangenomen. Het lijkt erop dat elke opvatting over het 'sacrale' en het 'seculiere' een religieuze visie verraadt en dat elk oordeel over de verhouding tussen cultuur, wetenschap en religie een specifiek filosofisch perspectief op de werkelijkheid vertegenwoordigt. Als deze gedachte juist zou zijn - ik formuleer dit bewust in de vorm van een hypothese - dan roept dit een aantal fundamentele filosofische vragen op. Ik noem er enkele. Op welke manier komen het 'sacrale' en het 'seculiere' in onze maatschappij naar voren? En welke maatschappelijke implicaties hebben die begrippen bijvoorbeeld in termen van uitsluiting of vervreemding? Hoe kunnen we een bepaalde visie op het 'sacrale' en het 'seculiere' legitimeren? En als er verschillende visies zijn op deze thematiek, hoe kan het filosofische debat dan vruchtbaar gevoerd worden?

Ik wil dit soort vragen aan de orde stellen vanuit één van de onderzoeksthema's van de Faculteit der Cultuur-en Maatschappijwetenschappen, namelijk die van 'innovatieculturen'. In het bijzonder wil ik mij richten op innovatie in de gezondheidszorg.

Mijn oratie heeft de volgende opbouw. Ik begin met het rijke roomse leven aan de hand van de muziek van Olivier Messiaen die laat zien dat de religieuze ervaring een deel van het alledaagse leven is (paragraaf 2). Vervolgens neem ik u mee in de wereld van de filosofie. Ik bespreek de visies van drie filosofen op het 'sacrale' en op het 'seculiere': de humanistische filosofen Bronislaw Szerszynski en Luc Ferry en de christelijke filosoof Herman Dooyeweerd. Deze denkers laten ieder op hun eigen manier zien dat moderniteit niet gekarakteriseerd kan worden als 'onttovering', maar als herordening van het sacrale (paragraaf3). Op basis van een analyse trek ik enkele voorlopige conclusies over het sacrale in de 
gezondheidszorg. Ik laat zien dat de verschillende verschijningsvormen daarvan met elkaar op gespannen voet staan en elkaar ook versterken. Met als gevolg dat de problemen in de gezondheidszorg alleen maar toenemen (paragraaf 4). Daarna gaan we onze zoektocht naar het sacrale in de gezondheidszorg voortzetten. We doen dit aan de hand van een empirisch onderzoek naar een innovatie in de psychiatrie. Tevens besteed ik aandacht aan de verschillende modellen die gebruikt worden om dit soort innovaties te begrijpen (paragraaf 5). Ik sluit af met een schets van mijn onderzoeksterrein (paragraaf 6), gevolgd door enkele conclusies (paragraaf 7) en een dankwoord (paragraaf 8).

\section{Olivier Messiaen: Diptyque pour orgue}

Ik wil graag beginnen met de 'rijke roomse cultuur'. Sinds 1991 hebben we als gezin in de provincie Limburg gewoond. Op allerlei manieren hebben de we roomse cultuur opgesnoven: het rijke verleden, de Bourgondische inborst en de kerkelijke tradities. Regelmatig kwamen we in een Rooms-Katholieke Kerk, onder andere bij kerkelijke feestdagen, heilige communies, huwelijken en begrafenissen. Op een van de begrafenissen werd tijdens de dienst een orgelwerk van Olivier Messiaen (1908-1992) ten gehore gebracht. Ik werd erdoor gegrepen. Ik was diep ontroerd. Waarom? Door de compositie? Door de diepere betekenis? Door de gehele context? De eerlijkheid gebiedt te zeggen: ik was geen orgelliefhebber, ik kon de muziek niet goed interpreteren en ik had nog nooit van de componist gehoord. Toch raakte de muziek mij: ik ervoer deze als een religieuze, existentiële ervaring.

Ik wil u graag iets van het werk van Messiaen laten horen. Ik heb gekozen voor een van zijn vroegere werken, het Diptyque pour orgue uit 1929. Messiaen heeft dit stuk gecomponeerd toen hij nog student was aan het Paris Conservatoire. Hij heeft het opgedragen aan zijn hoogleraren Paul Dukas en Marcel Dupré.

Hoe moeten we het Diptyque pour orgue interpreteren? Wat wil dit stuk precies uitdrukken? Wat is de relatie tussen compositie en betekenis? Om antwoord te krijgen op deze vragen is het belangrijk om enkele stappen op het terrein van de filosofie van de muziek te zetten. In een recente publicatie - Elke muziek heeft haar hemel. De religieuze betekenis van muziek - worden meerdere perspectieven genoemd die nodig zijn 
om muziek te 'begrijpen'3 Ik haal er drie naar voren: de compositie, de intenties en diepste overtuigingen van de componist, en de context waarin de muziek wordt gecomponeerd en beluisterd.

We beginnen met het eerste perspectief: de compositie van het stuk. ${ }^{4} \mathrm{Er}$ zijn grote verschillen tussen het eerste en het tweede deel. Het eerste deel wordt gekenmerkt door donkere registraties, korte motieven, heftige contrasten en snelle modulaties. De muziek maakt onrustig, roept gevoelens van neerslachtigheid op en is soms zelfs angstaanjagend. Het tweede deel is anders. Het tempo is langzaam, de harmonieën zijn vriendelijk en de klankkleuren zijn helder. Dit deel roept dan ook heel andere gevoelens op, zoals rust, vrede en harmonie. Ondanks de verschillen is er een duidelijke verbinding tussen beide delen: de melodie in mineur van het eerste deel is de basis voor de melodie in majeur van het tweede deel. Het is erg belangrijk om deze structurele kenmerken van het Diptyque pour orgue te begrijpen om het stuk te kunnen 'meevoelen' en 'meebeleven', en om je er aan 'over te geven'. Roger Scruton spreekt in dit verband over 'to hear with understanding'. 5

Het tweede perspectief dat nodig is om een muziekstuk te begrijpen betreft de intenties en de diepste overtuigingen van de componist. 'Als de componist zijn interpretatie niet zelf verschaft', zo schrijft muziekfilosoof Heijerman, 'dan is er geen criterium om uit te maken wat de correcte interpretatie is'. ${ }^{6}$ Daarom is het van belang om dit perspectief te verkennen. Olivier Messiaen was een praktiserend katholiek. Hij was getroffen door de heilige teksten uit de christelijke traditie en hij koesterde grote bewondering voor de werkelijkheid waarin we leven. Hij wilde de 'waarheden van het katholieke geloof' in zijn muziek uitdrukken. Messiaen was diep geraakt door de God van de bijbel, die geprobeerd heeft zich in onze taal, onze gevoelens en onze zienswijzen verstaanbaar te maken. En het mooiste aspect daarvan is volgens hem de komst van Jezus Christus op aarde. Messiaen geloofde in een leven na de dood, verwachtte een hemels Jeruzalem, en benadrukte de heerlijkheid van het leven aan 'gene zijde'. Daarmee komen we tot de thematiek van Diptyque pour orgue. In het eerste deel van dit stuk wordt het verdriet en het leed van het menselijk bestaan op deze aarde in schrille klanken 'verwoord'. Vandaar die donkere tonen, de felle contrasten en de diepe angst. Het tweede deel tekent echter de volmaaktheid van het eeuwige leven. Het rustige tempo, de vredige harmonieën en de heldere klanken voeren ons mee naar perfecte sereniteit. 
Ten slotte, nog een enkel woord over het derde perspectief. Martin Hoondert benadrukt dat muziek ook een sociale praktijk is waarin sprake is van een 'heen-en-weer' tussen componisten, uitvoerders en luisteraars. ${ }^{8}$ In dit geval is sprake van een religieuze context waarin mensen zich gezamenlijk overgeven aan muziek om spiritualiteit en transcendentie te ervaren.

Er is nog één punt dat ik naar voren wil halen. Messiaen was ervan overtuigd dat in de muziek een 'doorbraak naar gene zijde' mogelijk zou zijn. De verschillende klankcomplexen - hij spreekt van 'draaiende akkoorden', 'opeengestapelde transposities', 'samengetrokken resonanties' en 'getransponeerde omkeringen' - leiden tot een 'innerlijke kleursensatie'. Messiaen verwijst naar de visuele sensatie die 'de rozetten, de glasramen, en het glas-in-lood van de grote gothische kathedralen geven, iets verschrikkelijks en heiligs, waar je het fijne niet van begrijpt, die ons voert naar een wereld van licht dat te sterk is voor onze rede'. 9 De ervaring van een 'te sterk licht' ofwel de ervaring van 'verblinding', is in de ogen van Messiaen een religieuze ervaring. Het is de ervaring van iets dat onszelf en de werkelijkheid overstijgt. Het is de ervaring van transcendentie. Ik wil graag de idee van een 'religieuze ervaring' benadrukken. In de visie van Messiaen gaat het in zijn muziek niet om een symbolische of metaforische representatie van de inhoud van het christelijke geloof maar om het ervaren van dat geloof. ${ }^{10}$

Het ligt voor de hand om te denken dat Messiaen een aparte stijl heeft ontwikkeld om de religieuze ervaring op te wekken. Ook is te verwachten dat hij een sterk onderscheid maakt tussen sacrale en profane muziek. Toch is dat niet het geval. Hij legitimeert zijn visie met de verwijzing naar de ene werkelijkheid waarin we leven: 'Ik denk dat er geen werkelijk profane, noch werkelijk sacrale muziek bestaat, maar één werkelijkheid gezien vanuit verschillende hoeken.'11 In dit citaat komen twee belangrijke notities naar voren. Allereerst dat religie als fenomeen inherent is aan onze werkelijkheid en daarmee dat de religieuze ervaring inherent is aan het menszijn. Daarom is het ook mogelijk dat muziek mensen in een religieuze stemming kan brengen. Ik denk hierbij ook aan mijn hiervoor beschreven eigen ervaring. Ten tweede, er is geen scherpe scheidslijn tussen het sacrale en het seculiere. We kunnen alleen onderscheid maken tussen die ideeën als we op verschillende manieren naar de werkelijkheid kijken. 


\section{Denken over het sacrale en het seculiere}

In de loop van deze rede zijn we tot nu toe twee visies op het sacrale en het seculiere tegengekomen. Ik ben begonnen met de neoliberale visie op religie en op de openbare ruimte die gekenmerkt wordt door een scherpe scheiding tussen het sacrale en het seculiere. Daarna ben ik ingegaan op de visie van Messiaen die stelt dat het sacrale en het seculiere niet gescheiden kunnen worden, dat er sprake is van één werkelijkheid die op verschillende manieren bekeken kan worden.

Hoe moeten we deze twee visies begrijpen? Is de neoliberale visie wetenschappelijk gefundeerd? Behoort het denken van Messiaen tot het voorbije verleden (seculariseringsthese)? En is er een relatie tussen deze opvattingen? Om dieper inzicht te krijgen in deze vragen wil ik u graag meenemen in het denken van drie filosofen: de Engelse filosoof Bronislaw Szerszynski ( \pm 1960$)$, de Franse filosoof Luc Ferry (1951) en de Nederlandse filosoof Herman Dooyeweerd (1894-1977).

\subsection{Bronislaw Szerszynski: de lange boog van de transcendentale religie}

Bronislaw Szerszynski vraagt zich in zijn boek Nature, Technology and the sacred (2005) af hoe we de moderne tijd precies moeten beoordelen.12 Een wijdverbreide visie is die van Max Weber, de 'onttovering van de wereld': onder invloed van wetenschap en techniek hebben we de natuur gezuiverd van mysterieuze krachten en goddelijke ingrepen. We geloven niet meer in goden, demonen en geesten die ons kunnen helpen, hinderen of bang maken. ${ }^{3}$ We geloven tegenwoordig dat de werkelijkheid begrepen kan worden in wiskundige termen en natuurkundige wetten. Sterker nog, we kunnen de natuur beheersen door de wetenschap, haar potenties realiseren door techniek, en haar waarde bepalen in de markt. Samengevat, 'onttovering' wil zeggen dat 'religie is vervangen door wetenschap en techniek.' ${ }^{14}$

Szerszynski merkt op dat het moderne denken gekenmerkt wordt door een asymmetrische visie op het sacrale en het seculiere. Het seculiere wordt gezien als iets vanzelfsprekends, als iets wat geen verklaring nodig heeft. Maar het sacrale wordt gezien als iets afwijkends, als iets dat verklaard moet worden. ${ }^{15}$ Juist vanwege deze asymmetrie wil hij het seculiere 'problematiseren'. 
Szerszynski laat zien dat het verhaal van de onttovering veel complexer in elkaar zit dan in veel populaire en filosofische beschouwingen wordt beschreven. Hij wijst erop dat in de klassieke wereld het begrip 'werelds' of 'profaan' altijd religieus geduid werd. Hij verwijst daarbij naar de originele betekenis van het woord 'profaan': pro-fanum is de ruimte die zich voor het heiligdom bevindt. Ook verwijst hij naar Hans-George Gadamer die stelt dat het profane altijd het sacrale vooronderstelt. ${ }^{16}$ Anders gezegd, in het klassieke denken was het profane altijd een ruimte binnen een sacrale kosmos. Het moderne denken stelt echter dat de wereld volkomen profaan of seculier is en geen enkele spirituele betekenis heeft. In dit denken presenteert het seculiere zich als een 'self-grounding, independent reality'. ${ }^{77}$ Szerszynski wil deze visie op de werkelijkheid problematiseren. Hij is van mening dat het moderne denken de wereld niet heeft onttoverd, maar de ene betovering heeft vervangen door de andere. Hij vraagt zich zelfs af of we het verhaal van de onttovering van de natuur niet moeten zien als de 'creation myth of modern society'. ${ }^{18}$ Szerszynski laat dan ook zien dat de moderniteit en daarmee de moderne opvattingen over het sacrale en het seculiere - opgevat moet worden als een specifiek product van onze religieuze en culturele geschiedenis. Hij noemt het seculiere zelfs een religieus fenomeen. ${ }^{19}$ In zijn visie is het sacrale in de moderne tijd niet zozeer verdwenen, als wel op een andere manier geordend of georganiseerd.

Ik wil erop wijzen dat Szerszynski het woord 'sacraal' in algemene zin gebruikt. Hij schrijft: "I am using "sacred" in a more general sense, to understand the ways in which a range of religious framings are involved in our ideas of and dealings with nature and technology (...) it is the ground against which particular historical phenomena or ideas appear as intelligible figures'. ${ }^{20}$ Hij refereert aan de opvattingen van Kay Milton die het heilige definieert als 'what matters most to people' en aan de definitie van Paul Tillich die religie omschrijft als 'ultimate concern'. Daarnaast wil hij ook negatieve ervaringen als angst en vervreemding in religieuze termen duiden. ${ }^{21}$

Szerszynski beschrijft de ontwikkeling van het sacrale onder het kopje 'The Long Arc of Transcendental Religion'.22 Het verhaal begint met het primal sacred van inheemse volken die de werkelijkheid ervaren als een eenheid van het natuurlijke en het goddelijke. Zij maken geen onderscheid tussen het empirische en het transcendente, het seculiere en het sacrale. Een volgende stap in de ontwikkeling is het archaic sacred, 
zoals we dat bijvoorbeeld vinden in de religieuze systemen van Afrika en Polynesië, en in de heidense culturen in West-Europa, die voorafgingen aan de verspreiding van het christendom en de islam. In deze systemen en culturen wordt de werkelijkheid ook ervaren als een eenheid van het natuurlijke en het goddelijke. Tevens zien we dat de godheden meer specifieke goden zijn waarmee de mens op een geordende manier communiceert. In het archaïsch sacrale hebben sommige objecten, plaatsen of personen een geprivilegieerde relatie met het sacrale waarbij andere dingen als relatief seculier worden gezien.

Een meer substantiële transformatie vindt plaats met de verschijning van het monotheistic sacred van de historische religies als het judaïsme, christendom en islam. In deze transformatie wordt het kosmologisch monisme van de archaïsche religie geordend langs een verticale as: er wordt een onderscheid gemaakt tussen de 'wereld hier beneden' en de 'transcendente wereld hier boven'. Er ontstaat een dualisme tussen 'natuur'en 'bovennatuur'. Het gevolg van dit dualisme is, aldus Szerszynski, dat het transcendent goddelijke uit de empirische werkelijkheid wordt verdreven. Daarmee krijgen religieuze plaatsen als kerken en kapellen een nieuwe betekenis: ze verwijzen naar de Transcendente die 'boven' is. Daarnaast komt het begrip 'verlossing' centraal te staan in de religie. Filosofisch gezien is deze fase van groot belang omdat begrippen als 'één waarheid', 'natuur' en 'samenleving' zich ontwikkelen.

Een volgende stap in de ontwikkeling is het Protestant sacred waarin de hiërarchie tussen het bovennatuurlijke en het natuurlijke wordt ontmanteld of verwijderd. Het gevolg is dat de kloof tussen het transcendente goddelijke en het wereldlijke gezien wordt als oneindig groot én oneindig klein, als absoluut én in het niets verdwijnend. In deze transformatie zien we twee dingen. Enerzijds wordt de Transcendente getekend als de Verhevene, de Almachtige. Anderzijds is Hij nabij en direct toegankelijk voor het individu, zonder hemelse of aardse intermediair. Het protestantse sacrale opent de weg voor het individu - geschapen naar het beeld van God - om op alle gebieden van het profane leven God te dienen. De hele wereld, in al zijn complexiteit en dynamiek, is zijn of haar terrein. Szerszynski gebruikt het woord 'profaan' hier vrijwel in zijn oorspronkelijke betekenis: het 'profane' is direct gerelateerd aan het sacrale en krijgt betekenis vanuit het sacrale. 
Met het modern sacred, dat de Verlichting en de Romantiek omvat, wordt de verticale transcendente as in toenemende mate in de empirische wereld getrokken. In het monotheïstische en protestante sacrale werd het 'zijn' en de 'orde' in de natuur gerelateerd aan een 'bovennatuurlijke oorsprong', maar in het moderne sacrale worden ze steeds meer gezien als eigenschappen van de werkelijkheid zelf. De wereld wordt profaan in een geheel nieuwe betekenis. Namelijk als een ruimte die alleen profaan is en die geen relatie heeft met het sacrale. Het profane is 'totaal' of 'absoluut' geworden. ${ }^{23}$ Om de 'kanteling' van deze verticale as te beschrijven gebruikt Szerszynski woorden als 'ineenstorten' en 'introjecteren'.24 Deze ineenstorting of introjectie leidt echter niet tot het verdwijnen van het sacrale maar tot een herordening van het sacrale: de sacraliteit van het menselijke subject en de sacraliteit van de levensprocessen. ${ }^{25}$ Met andere woorden, de mens kent zichzelf en de natuur een goddelijk karakter toe. De herordening van het sacrale leidt ook tot een nieuwe visie op verlossing. De verlossing door Christus wordt vervangen door zelfverlossing. In de traditie van de Verlichting wordt de nadruk gelegd op de weg van wetenschap en techniek en in de traditie van de Romantiek op authenticiteit en verbondenheid met de wereld. Ik wijs erop dat het moderne sacrale blijft vasthouden aan de idee van de 'ene waarheid' over de werkelijkheid zoals die zich in het monotheïstisch heilige heeft ontwikkeld.

Als laatste komen we tot het postmodern sacred, waarin het monotheïstisch heilige en het protestants heilige radicaal ineengestort zijn. Er ontstaat een veelvoudige werkelijkheid die gevuld is met en geconstitueerd wordt door verschillende visies op mens en werkelijkheid die gefundeerd zijn in de subjectieve ervaring. Mensen richten zich niet meer naar een natuurlijke of goddelijke orde, maar kiezen voor een eigen levensbeschouwing op basis van 'wat goed voelt' en geven hun eigen religie vorm. De kern van het postmoderne sacrale is dat het post-transcendentaal is: het kan alleen bestaan na het tijdperk van het transcendentale monotheïsme. De idee van eenheid, die in het moderne sacrale nog aanwezig was, heeft plaatsgemaakt voor pluraliteit.

Szerszynski geeft met zijn 'Long Arc of Transcendental Religion' een bijzonder boeiende schets van de geschiedenis van het sacrale en het seculiere. De waarde van deze schets is dat hij laat zien dat ons huidige denkklimaat het resultaat is van een langdurig 'historisch proces'. Hij laat zien dat dit langdurige proces niet heeft geleid tot het verdwijnen van het sacrale - wat door veel politici en filosofen wordt gesteld - maar 
tot een herordening van het sacrale. Om het met de woorden van Latour te zeggen: 'We zijn nooit modern geweest'. ${ }^{26}$ Ten slotte geeft zijn schets allerlei aanknopingspunten om het sacrale en het seculiere, het heilige en het profane in onze samenleving onder woorden te brengen.

Hoe staat Szerszynski zelf in deze lange boog? Szerszynski maakt zijn eigen positie niet helder. Hij suggereert dat het postmoderne heilige geen antwoord kan geven op de vragen en de problemen van onze globale samenleving omdat de laatste grond van waarden en zingeving gefundeerd worden in de menselijke subjectiviteit. Met andere woorden, het postmoderne heilige levert geen stevige basis voor een kritiek van de moderne samenleving. ${ }^{27} \mathrm{Hij}$ pleit voor een ordening van het heilige waarin pluraliteit en eenheid met elkaar verbonden worden. Hij zoekt naar een idee van een transcendente as die een pluraliteit van perspectieven op de werkelijkheid mogelijk maakt. ${ }^{28}$

\subsection{Luc Ferry: radicale breuken in de cultuur}

De Franse filosoof Luc Ferry geeft in zijn boek Beginnen met filosofie. Met andere ogen kijken naar je leven (2006) een overzicht van de geschiedenis van de filosofie. ${ }^{29} \mathrm{Hij}$ is van mening dat we de filosofie nodig hebben om iets te kunnen 'begrijpen van de wereld waarin we leven' en om ons te helpen een 'beter en vrijer leven te leiden'. ${ }^{\circ}$ In zijn visie draait het in de filosofie om de vraag naar de eindigheid van het menselijke leven. Hij maakt daarbij een scherp onderscheid in de manier waarop religie en filosofie met dit vraagstuk omgaan. In religie draait het volgens hem om het vertrouwen in God en in filosofie om het vertrouwen in onszelf. Hij schrijft ${ }^{31}$ :

"Met andere woorden, waar de religies zichzelf definiëren als "heilsleren" door toedoen van een Ander, dank zij God, zouden we belangrijkefilosofieën kunnen definiëren als heilsleren door toedoen van onszelf, zonder hulp van God.'

Ferry richt zijn aandacht op drie onderdelen van de filosofie: het begrijpen van de werkelijkheid (theorie), het verlangen naar rechtvaardigheid (ethiek) en het zoeken naar het heil (wijsheid). Het zal duidelijk zijn dat hij met deze driedeling aansluit bij de drie vragen van de bekende filosoof Immanuel Kant: 'Wat kan ik weten?', 'Wat moet ik doen?' en 'Wat mag ik hopen?' Ik wil vooral aandacht geven aan het eerste onderdeel: het begrijpen van de werkelijkheid. 
Het opgroeien van kind tot volwassene zou je kunnen omschrijven als het leren kennen van je eigen plaats in de wereld. Naarmate we ouder worden krijgen we-als het goed is - steeds meer inzicht in onszelf en in de manier waarop we in het leven staan. Het inzicht in de werkelijkheid wordt in het Grieks theoria genoemd. Het is belangrijk om even stil te staan bij de etymologie van dit woord. To theion of ta theia orao betekent 'ik zie het goddelijke' of 'ik zie goddelijke dingen'.32 Volgens de Griekse filosofen was the-oria inderdaad een poging om het goddelijke in de kosmos te aanschouwen. En hier ben ik zo vrij om een verbinding te leggen met het denken van Szerszynski: Ferry verkent op zijn eigen manier de ontwikkeling van het goddelijke of het sacrale in de geschiedenis.

Ferry gaat met zevenmijlslaarzen door de geschiedenis van de filosofie. $\mathrm{Hij}$ begint met een bespreking van de visie van de stoïcijnen. Volgens deze school kunnen we de werkelijkheid zien als een levend organisme of als een reusachtig wezen dat op volmaakte wijze is samengesteld. Elk orgaan vervult een fraaie functie, bevindt zich op de juiste plaats en werkt met de andere organen op een harmonieuze manier samen. Deze geordende structuur noemen de Grieken het 'goddelijke'. Dit goddelijke heeft niets gemeen met de persoonlijke God van het christendom maar heeft betrekking op de onpersoonlijke orde in de werkelijkheid. De prachtige ordening van de werkelijkheid wordt door de Grieken aangeduid met de term logos (waarvan ons woord 'logica' is afgeleid). Door het beoefenen van de theoria kunnen we deze ordening begrijpen en doorgronden. De logos heeft een immanent karakter: het bevindt zich in de werkelijkheid zelf en niet daarbuiten. Maar het heeft ook een transcendent karakter: het staat volledig boven de mens en is dus niet door de mens gemaakt. Ik wil nog even kort de verbinding leggen naar de twee andere onderdelen van de filosofie. Allereerst, omdat de kosmos niet alleen harmonisch maar ook rechtvaardig en goed is, dient ieder mens te ontvangen wat hem of haar toekomt. Hier vinden we de verbinding met de ethiek. Daarnaast, omdat elk mens deel uitmaakt van die goddelijke orde, betekent de dood geen definitief einde maar de overgang naar een andere toestand: hier vinden we de relatie tot de heilsleer.

Luc Ferry laat zien dat de opkomst van het christendom een radicale breuk met het Griekse denken betekent. Dat komt het duidelijkst naar voren op het gebied van de theoria. Het goddelijke wordt niet langer gelijkgesteld met de kosmische orde maar neemt de gedaante aan van een persoon: Jezus Christus. De radicaliteit van die breuk blijkt duidelijk uit de proloog van het evangelie van Johannes (Johannes 1): 
' 1 In het begin was het Woord [logos], het Woord [logos] was bij God en het Woord [logos] was God. 2 Het was in het begin bij God. 3 Alles is er door ontstaan en zonder dit is niets ontstaan van wat bestaat ... 14 Het Woord [logos] is mens geworden en heeft bij ons gewoond, vol van goedheid en waarheid, en wij hebben zijn grootheid gezien, de grootheid van de enige Zoon van de Vader.'

De stoïcijnen zouden het met de eerste drie verzen waarschijnlijk wel eens zijn. Maar bij het veertiende vers gaat het mis. De gedachte dat het goddelijke mens is geworden - en dat de discipelen de getuigen waren van deze menswording - is voor hen de 'waanzin ten top'.33 In het Griekse denken viel de logos samen met de onpersoonlijke, harmonieuze en goddelijke structuur van de kosmos. Maar in de visie van de apostel Johannes wordt de logos vereenzelvigd met een persoon: Jezus Christus. De breuk met de Griekse visie op het goddelijke heeft geweldige gevolgen voor andere onderdelen van de filosofie. De natuurlijke orde als basis voor de ethiek wordt vervangen door 'de wet van de liefde'. En de anonieme en onpersoonlijke eenwording met de kosmos maakt plaats door een individuele verlossing en een persoonlijke opstanding.

Het ontstaan van de moderne filosofie - het tijdperk van het humanisme - gaat uiteindelijk gepaard met de ineenstorting van de klassieke kosmologie (het Griekse denken) en met het afwijzen van het religieuze gezag (het christendom). We krijgen te maken met een tweede radicale breuk in de geschiedenis van de westerse cultuur. De ineenstorting van de Griekse kosmos en het ter discussie stellen van het religieuze gezag betekent dat de moderne mens op eigen kracht de kernvragen van de filosofie met betrekking tot de theorie, de ethiek en het heil weer opnieuw moet stellen. Theoria is niet langer het 'zien van het goddelijke' maar is vervangen door het 'zelf orde scheppen'.34 De mens neemt de gigantische taak op zich om orde te scheppen in een onttoverde kosmos. Door middel van de wetenschap legt de mens zelf de relatie tussen de verschillende verschijnselen in de werkelijkheid: de theoria als sociale constructie. Ferry is van mening dat we hier te maken hebben met een radicale breuk omdat in het moderne denken de mens het middelpunt van de wereld wordt. Hij of zij neemt de plaats in van de kosmos (Griekse denken) en van de godheid (christendom). ${ }^{35}$ Met als gevolg dat de mens ook de grondslag wordt voor de ethiek en dat hij of zij ook aan de basis van het heil ligt. 
In zijn boek De god-mens of de zin van het leven (1996) beschrijft Ferry de ontwikkeling van de moderniteit met behulp van twee lijnen. ${ }^{36}$ Als eerste tekent hij hoe de moderne theologie bijdraagt tot de vermenselijking van het goddelijke. Daarnaast tekent hij de denkweg van het humanisme waarin een vergoddelijking van het menselijke plaatsvindt. Beide lijnen impliceren dat de goddelijke 'versie' van het sacrale plaats maakt voor een menselijke versie.

Ik kom nu tot de visie van Luc Ferry op de postmoderniteit. Hij laat zien dat er een radicale breuk is met het moderne denken. Ferry geeft vooral aandacht aan het 'geval Nietzsche'. In de visie van Friedrich Nietzsche blijven de nazaten van de moderniteit gevangen in de grondstructuren van de religie omdat ze blijven geloven in waarden die "hoger dan het leven zijn', zoals de rechten van de mens, wetenschap, rede, sociale rechtvaardigheid, democratie, enzovoorts. Nietzsche presenteert zich als de filosoof 'met de hamer' die de oude idealen - in zijn terminologie 'afgodsbeelden' - wil afbreken. Hij is er van overtuigd dat alle idealen een zelfde structuur en doel hebben. Namelijk, het bedenken van waarden die boven de mens uitstijgen en het verzinnen van een hiernamaals dat beter is dan dit aardse leven. In de visie van Nietzsche is de werkelijkheid geen orde of harmonie maar een oneindige veelheid van krachten en driften die niet tot een eenheid te herleiden zijn en voortdurend met elkaar botsen. In de ethiek gaat het dan ook om de scheppende waarden van de mens, de 'grote levensstijl', de 'wil tot macht'. En ons heil ligt in een leven dat waard is om geleefd te worden. Een intens, verheven en moedig leven. Een leven waarin geen ruimte is voor spijt en berouw.

Luc Ferry markeert op heldere wijze zijn eigen positie. Hij is van mening dat we op geen enkele manier terug kunnen naar het verleden en dat we ons ook niet kunnen 'opsluiten in het denken met de hamer'.37 Hij pleit voor een 'postnietzscheaanse wijsheid' of een 'humanisme na de deconstructie' dat erin slaagt om de theoria, de moraal en het heilsvraagstuk weer in nieuwe termen te denken. ${ }^{38} \mathrm{Hij}$ verdedigt een rehabilitatie van het begrip transcendentie. Hij wijst erop dat waarden als 'waarheid', 'schoonheid', 'rechtvaardigheid' en 'liefde' niet door de mens bedacht worden maar dat deze zich aan de mens 'opdringen' en dat hij erdoor 'overvallen' wordt. $39 \mathrm{Hij}$ stelt dat deze waarden zich 'in mij' doen kennen (immanentie) en toch van buiten komen (transcendentie)..$^{40} \mathrm{Hij}$ geeft 'liefde' als voorbeeld. Als ik verliefd word, dan ervaar ik een gevoel in mij dat door een wezen van buiten wordt veroorzaakt. Met andere woorden, 'transcendentie binnen de immanentie'. ${ }^{41}$ 


\subsection{Herman Dooyeweerd: gedreven door grondmotieven}

Als laatste wil ik ingaan op de visie van Herman Dooyeweerd op de geschiedenis van de filosofie. De eerste reden daarvoor is dat hij een heel eigensoortige benadering van de problematiek geeft. De tweede reden is dat de bijzondere leerstoel die ik bekleed is ingesteld door de Stichting voor Reformatorische Filosofie, waarvan Herman Dooyeweerd één van de oprichters was.

Herman Dooyeweerd benadrukt - ik volg hier in grote lijnen zijn boek Vernieuwing en Bezinning - dat de culturele, wetenschappelijke en geestelijke ontwikkeling van de westerse cultuur in hoge mate beheerst wordt door religieuze motieven. ${ }^{42}$ Het woord 'religie' gebruikt Dooyeweerd hier in een brede betekenis: het gaat om de 'geestelijke drijfkracht' of diepste motieven van een cultuur.43 Om het fundamentele karakter van deze motieven te benadrukken spreekt hij van 'grondmotieven'. Dooyeweerd onderscheidt vier religieuze grondmotieven die in achtereenvolgende perioden in de geschiedenis hun stempel hebben gezet op de cultuur en de filosofie. In de Griekse en Helleense Oudheid domineerde het motief van vorm en materie, in de periode kort na het begin van de christelijke jaartelling het bijbelse motief van schepping, zondeval en verlossing, in de Middeleeuwen het rooms-katholieke motief van natuur en genade, en vanaf de Renaissance het humanistische motief van natuur en vrijheid. Dooyeweerd wijst erop dat de opkomst van een nieuw grondmotief als 'leidende macht' niet betekent dat een voorgaand motief wordt uitgeschakeld, maar dat deze (tijdelijk) in het defensief wordt gedrongen. Met andere woorden, grondmotieven kunnen in de cultuur blijven doorwerken.

We beginnen met het motief van vorm en materie.44 De Griekse filosofie wordt volgens Dooyeweerd gekarakteriseerd door een onverzoenbaar conflict tussen twee motieven: het religieus bewustzijn van de oude natuurgodsdiensten en de nieuwe religie van de olympische godenwereld. De oude natuurgodsdienst werd gekenmerkt door het geloof in de goddelijke levenstroom waarin alles opkomt en alles onder gaat. Het is een religie van de duistere materie die beheerst wordt door het lot. De nieuwe religie, die in de Griekse polis of stadstaat tot bloei kwam, werd gekenmerkt door vorm, maat en harmonie. De olympische goden verlaten 'moeder aarde' met haar kringloop en vestigen zich als goden met een persoonlijke gestalte op de berg Olympus. Aan de ene 
kant is er een hoge mate van samenhang tussen de oudere natuurreligie en de nieuwere cultuurreligie. Maar aan de andere kant is er ook spanning tussen de aardse materie van de natuurreligie en de hemelse vormen van de cultuurreligie. En deze spanning bleef volgens Dooyeweerd het Griekse denken beheersen.

Het tweede motief is het bijbelse motief van schepping, zondeval en verlossing. ${ }^{45}$ Dooyeweerd stelt dat dit motief zich antithetisch verhoudt ten opzicht van het Griekse denken. In de bijbel wordt God getekend als Schepper terwijl in het Griekse denken de Demiurg - de 'redelijke vormgod' - niet de oorsprong van de materie is maar deze alleen vormt. En de goddelijke rede kan de duistere krachten van de materie - het blinde lot - alleen door overreding beteugelen. Dooyeweerd stelt dat de idee van de schepping integraal en radicaal is. Dat wil zeggen, het omvat heel de werkelijkheid en dringt door tot de 'wortel' of de 'oorsprong' van die werkelijkheid. Deze idee bepaalt ook zijn visie op de mens. Hij belijdt dat de mens geschapen is naar het beeld van God. Dit betekent dat de mens mag leven en werken in de gerichtheid op de Schepper en in nauwe verbondenheid met de medemens. Ook het tweede element van het bijbelse motief - de zondeval - staat volgens Dooyeweerd loodrecht op de Griekse opvattingen. Het Griekse denken kende slechts de strijd tussen het materie- en het vormprincipe in de mens. Dit komt naar voren in het conflict tussen de 'zinnelijke begeerten' en de 'leiding van de rede'. In het bijbelse denken daarentegen vindt het kwaad zijn oorsprong in het hart van de mens: de 'autonome' mens die zich van God afkeert en zich daarmee van de medemens en de natuur vervreemdt. De idee van de zondeval is - evenzo als de idee van de schepping - integraal (het heeft betrekking op alles) en radicaal (hart als religieus centrum van de mens). Ten slotte het laatste element: de verlossing. De verlossing vindt haar oorsprong in een persoon: Jezus Christus, het vlees geworden woord. Deze verlossing is ook integraal (omvat mens, medemens en natuur) en radicaal (grijpt aan in het hart van de mens, 'wedergeboorte').

Het derde grondmotief is het rooms-katholieke motief van natuur en genade. ${ }^{46}$ In de loop van de geschiedenis zijn er veel pogingen ondernomen om het Griekse en joods-christelijke denken te integreren. In de Middeleeuwen leidde dit tot een wijsgerig hoogtepunt: de filosofie van Thomas van Aquino, die vele eeuwen het rooms-katholieke denken zou beheersen. Centraal in zijn denken staat de gedachte dat God de werkelijkheid heeft geschapen als 'materie' en 'vorm'. De materie komt 
naar voren in de mens als natuurlijk wezen dat samengesteld is uit een 'materie-lichaam' en een 'redelijke ziel'. De vorm komt naar voren in het boven-natuurlijke vermogen van de mens waardoor hij in zijn denken en handelen in overeenstemming met de bedoeling van de Schepper kan leven. In het thomistische denken is er geen tegenstelling tussen geloof en rede: het geloof richt zich op het terrein van de religie en de rede op het terrein van de filosofie. Het bovennatuurlijke vermogen tot geloof ging door de zondeval verloren waardoor de mens 'overgeleverd' werd aan de natuur. Het is nu juist de genade van God - die bemiddeld wordt door de kerk - waardoor de natuur gecorrigeerd en vervolmaakt wordt door het bovennatuurlijke. Tegelijkertijd wordt er een 'hiërarchie' geponeerd: de natuur als 'lagere voortrap' van de genade. Dooyeweerd meent dat het rooms-katholieke grondmotief van natuur en genade een inherente spanning met zich meedraagt omdat beide 'polen' niet inherent met elkaar verbonden zijn.

Het laatste grondmotief is het humanistische motief van natuur en vrijheid.47 Dit grondmotief vindt haar oorsprong in de Renaissance waarin de wedergeboorte van de nieuwe mens centraal staat. De gedachte dat de kerk iets te zeggen zou hebben over mens en cultuur, kunst en wetenschap, en politiek en samenleving werd afgewezen. Het ideaal was een nieuwe mens die zich veelzijdig zou ontwikkelen tot een universele mens. In deze stroming kwam de mens steeds meer in het middelpunt te staan. Pico della Mirandola laat in zijn boek Rede over de menselijke waardigheid (1486) God tot Adam zeggen dat hij 'midden in der wereld' is gezet en dat hij 'als vrij en soeverein kunstenaar' zichzelf mag vormgeven. ${ }^{48}$ Met andere woorden, wedergeboorte door jezelf vorm te geven, door zelfbepaling. Bij Pico della Mirandola komen we het moderne humanistische credo van de menselijke autonomie dus al tegen. De nieuwe mens treedt de natuur dan ook met een heel andere houding tegemoet. In negatieve zin gaat het om het beheersen van de krachten van de natuur die de menselijke vrijheid bedreigen en in positieve zin gaat het om het beheersen van de natuur als speelveld van de menselijke vrijheid. Dooyeweerd laat zien dat er een spanning is tussen natuur en vrijheid - ook wel geformuleerd als de spanning tussen het persoonlijkheidsideaal en het wetenschapsideaal. In de moderne wereld zien we die spanning op allerlei manieren terug: de wetenschappelijke, technocratische en politieke beheersing van onze maatschappij bedreigt de menselijke vrijheid. Tegelijkertijd wordt de menselijke vrijheid, vooral in de vorm van religie, gezien als een bedreiging voor de ontwikkeling van wetenschap, technologie en samenleving. 
Herman Dooyeweerd markeert ook op heldere wijze zijn eigen positie. Hij stelt dat wetenschap naar haar aard nooit neutraal kan zijn en altijd gedreven wordt door een grondmotief. Hij komt er expliciet voor uit dat zijn denken gedreven wordt door het joods-christelijke geloof zoals dat samengevat wordt in de motieven van schepping, zondeval en verlossing. Hij meent dat dit grondmotief als enige geen dialectische spanning kent omdat het integraal en radicaal denkt vanuit de openbaring van God als Schepper.

\subsection{Evaluatie}

We zien een hoge mate van overeenstemming tussen de analyses van Bronislaw Szerszynski, Luc Ferry en Herman Dooyeweerd. De drie denkers laten zien dat er radicale veranderingen hebben plaatsgevonden in de geschiedenis van onze cultuur. Szerszynski duidt deze veranderingen als transformaties van het sacrale, Luc Ferry als fundamentele breuken in het 'zien van het goddelijke' en Dooyeweerd als de opkomst van nieuwe religieuze grondmotieven. De drie denkers verhouden zich expliciet tot de (post-)moderniteit en pleiten voor herstel van het begrip 'transcendentie'. Luc Ferry pleit voor 'transcendentie binnen immanentie', Bronislaw Szerszynski voor een transcendente as die een pluraliteit van perspectieven mogelijk maakt, en Herman Dooyeweerd belijdt een transcendente Schepper. De overeenstemming vinden we name in de idee dat we de diepste waarheden ('ultimate beliefs') niet in het individuele menselijke subject kunnen funderen en dat fundamentele waarden met betrekking tot mens en natuur op de een of andere manier inherent aan de werkelijkheid zijn en zich als het ware van buitenaf aan ons opdringen.

Bronislaw Szerszynski en Herman Dooyeweerd laten zien dat de verandering van het christelijke denken naar het (post-)moderne denken niet als 'onttovering' beschreven kan worden maar als - om de terminologie van Szerszynski te gebruiken - een herordening van het sacrale. Ook Luc Ferry zal zich in deze formulering kunnen vinden. Hij zou die herordening karakteriseren als 'de mens is God geworden'. Charles Taylor laat in zijn monumentale werk Seculiere tijd uitvoerig zien dat de overgang van het christelijke denken naar het moderne denken een bijzonder complex proces is dat voorbereid werd door verschuivingen in het christelijke denken en dat zich niet laat beschrijven in simpele termen als 'onttovering'. 49 
Bronislaw Szerszynski en Herman Dooyeweerd verwerpen beide de hiërarchische ordeningen van de moderniteit. Szerszynski pleit voor een herstel van de symmetrie tussen het sacrale en het seculiere, religie en wetenschap, en samenleving en technologie. Hij doet dit in het bijzonder door het begrip 'seculier' te problematiseren. De positie van Dooyeweerd kunnen we zelfs als 'omkering' karakteriseren. Hij stelt dat elke filosofie en alle wetenschap een religieuze wortel heeft. Daarnaast benadrukt hij dat filosofie en wetenschap alleen bedreven kunnen worden in het kader van onze alledaagse ervaring van de werkelijkheid. ${ }^{\circ 0}$ Die alledaagse ervaring vormt - om een term van Hubert Dreyfus en John Searle te gebruiken - de achtergrond waartegen we denken en onderzoeken..$^{51}$ In de moderne techniekfilosofie - in het bijzonder in de Science, Technology and Society studies - speelt het begrip 'symmetrie' een belangrijke rol. Ik verwijs hierbij in het bijzonder naar het werk van Callon en Latour. ${ }^{2}$

Ten slotte nog iets over het huidige denkklimaat. Szerszynski laat zien dat de huidige tijd niet 'eenduidig' in termen van moderniteit of postmoderniteit beschreven kan worden. In zijn visie speelt het premoderne denken nog steeds een rol. Dooyeweerd is ook van mening dat dit soort eenduidige karakteriseringen niet mogelijk zijn. Bij hem komt dit tot uitdrukking in zijn stelling dat de verschillende grondmotieven in de cultuur blijven doorwerken.

\section{Het sacrale in de gezondheidszorg}

Een belangrijk onderzoeksthema in de Faculteit der Cultuur- en Maatschappijwetenschappen is Innovation cultures. Ik wil bijdragen aan dit thema door onderzoek te doen naar innovatie in de gezondheidszorg. Er zijn enkele belangrijke maatschappelijke redenen om hieraan aandacht te besteden. In de eerste plaats stelt de 'dubbele vergrijzing' ons voor een geweldige uitdaging. In de periode $2010-2040$ zal het aantal ouderen vrijwel verdubbelen terwijl de totale bevolkingsomvang ongeveer gelijk blijft. Tevens zal in dit tijdvak het aantal chronische zieken met diabetes, hartfalen, CVA, dementie, en andere aandoeningen met ongeveer dertig tot vijftig procent toenemen. Dit betekent een buitengewone inspanning om in de toekomst aan iedere burger die zorg te geven die hij of zij nodig heeft. Velen zijn van mening dat dit probleem opgelost moet worden door innovaties. In de tweede plaats 
blijkt uit onderzoek naar de leefsituatie van ouderen en chronisch zieken dat - ondanks de grote vorderingen in de medische wetenschap - er geweldige uitdagingen liggen op het gebied van welzijn en zingeving. De uitkomsten van deze onderzoeken wekken de suggestie dat de gezondheidszorg en/of de samenleving verkeerde prioriteiten stelt.

Zou het kunnen dat de bovengenoemde uitdagingen op het gebied van de gezondheidszorg - ik denk hierbij aan de analyses van Szerszynski, Ferry en Dooyeweerd - op de een of andere manier te maken hebben met de herordening van het sacrale? Zou het kunnen dat de sleutel tot dit soort uitdagingen niet ligt in het meetbare (wetenschap), het beheersbare (techniek) en verhandelbare (economie), maar in het heilige dat zich niet laat meten, beheersen en verhandelen? Zou het kunnen dat onze omgang met de gezondheidszorg religieuze trekken heeft? Zou het kunnen dat we in deze tijd juist onze aandacht moeten richten op de religieuze drijfveren van onze samenleving?53

De eerlijkheid gebiedt te zeggen dat aan dit soort vragen een andere vraag voorafgaat. Namelijk, of het wel terecht is om in dit verband woorden als 'sacraal' en 'religie' te gebruiken. ${ }^{54}$ Voor Messiaen zou dat vanzelfsprekend zijn, terwijl neoliberale denkers daar moeite mee zouden hebben. Ik ben van mening dat er toch een aantal argumenten is om met betrekking tot dit soort vragen en problemen toch het woord 'religieus' te gebruiken. Allereerst, in de gezondheidszorg gaat het juist om de vraag naar het 'goede leven'. Het gaat om de vraag naar betekenis en zingeving. Dan komt aan de orde wat voor iemand onaantastbaar is, wat zijn of haar 'laatste zekerheden' zijn, welke waarden hij of zij niet ter discussie wil stellen. Het gaat om overgave aan 'existentiële waarheden'. En dit soort fundamentele noties mogen we als 'religieus' karakteriseren. In de tweede plaats spelen in onze samenleving lichamelijke, sociale en spirituele perfectie een bijzonder belangrijke rol. We hebben er letterlijk alles voor over om het verouderingsproces - dat overigens volgens de nieuwste wetenschappelijke inzichten al in de baarmoeder begint - tegen te gaan en om ons niet-volmaakte zelf te modelleren naar de laatste normen van perfectie. Dit 'alles ervoor over hebben' komt niet alleen naar voren in het handelen van individuen maar ook in het handelen van de gehele samenleving. Denk onder andere aan de vele honderdduizenden geiten, varkens en koeien die de laatste decennia in ons land 'geruimd' zijn om onze gezondheid te beschermen. Dit 'alles ervoor over hebben' vertoont veel overeenkomsten met het rituele offer: 
het uitdrukken van vertrouwen, het gunstig stemmen van de godheid, het vragen om vergeving van schuld, en het danken voor gekregen zegen. 55 Luc Ferry stelt dat offeren een essentieel element van het heilige is (het heilige: le sacré en het offer: le sacrifice). ${ }^{56}$ In de derde plaats, in de geschiedenis van de medische wetenschap en de medische technologie speelt de idee 'als God worden' een belangrijke rol. Het gaat hier om de gedachte dat het ontrafelen van de geheimen van mens en natuur ons de mogelijkheid biedt om als schepper of mede-schepper vorm te geven aan ons eigen leven. Ik verwijs hiervoor onder andere naar het boek The Religion of Technology (1997) van David Noble over 'collectieve mythen' die de ontwikkeling van wetenschap en techniek bepalen. ${ }^{57}$ Dit soort motieven kunnen we nauwelijks anders dan 'religieus' typeren.

Welke rol speelt het sacrale in de gezondheidszorg? Ik wil proberen vanuit filosofisch perspectief enkele hoofdlijnen naar voren te halen. Ik zal daarbij essentiële nuanceringen, relevante uitwerkingen, belangrijke zijpaden en inherente complexiteiten moeten laten liggen. Ik hoop dat $u$ mij dat vergeeft. In dit verband zou ik een viertal fenomenen naar voren willen brengen: sacralisering van de medische wetenschap, sacralisering van de markt, sacralisering van het vitale leven en sacralisering van het individu.

1.Sacralisering van de medische wetenschap. De gezondheidszorg-vroeger spraken we van 'ziekenzorg' - wordt steeds meer op wetenschappelijke en technologische leest geschoeid. De gedachte is dat de essentie van ziekte en gezondheid in meetbare getallen begrepen en vastgelegd kan worden. We kunnen onze gezondheid beheersen en zijn in hoge mate onkwetsbaar geworden. Daarnaast streven we ernaar om elke afwijking en elke ziekte met behulp van een 'evidence based' methodiek te behandelen. De sacralisering van de medische wetenschap komt tot uiting in verschillende fenomenen: (a) de ondergeschikte positie van de niet-medische zorg, (b) de ondergeschikte positie van de patiënt in het behandelproces, (c) de belofte van de gezondheidszorg dat zij 'aards heil' kan bieden, en (d) het niet kunnen hanteren van de vraag naar welzijn en zingeving in het geheel van de medische behandeling.

2. Sacralisering van de markt. In overeenstemming met het moderne heilige kan de waarde van schaarse goederen in de gezondheidszorg op economische wijze bepaald worden. Ik denk hierbij onder andere aan diagnose-behandelcombinaties (DBC's) en zorgzwaartepakketten 
(ZZP's). De leidende gedachte is dat marktwerking leidt tot lagere kosten en betere kwaliteit. Een andere is dat uitwassen van marktwerking, zoals het uitsluiten van patiënten met een hoge 'schadelast', voorkomen moeten worden door regulering door de overheid. We spreken dan ook over gereguleerde marktwerking. De vraag of de gezondheidszorg een markt is lijkt in 'het' centrum van de macht niet meer aan de orde te zijn. Toch dient deze vraag wél gesteld te worden. Allereerst omdat de relatie tussen arts en patiënt per definitie asymmetrisch is: de patiënt zoekt hulp bij de arts. Tegelijkertijd is deze relatie ten diepste een morele relatie. Het gaat niet om een de medische ingreep 'sec'; het gaat om zorg voor een afhankelijk medemens. Deze twee factoren laten zien dat het problematisch is om de zorg als markt te karakteriseren. In de markt gaat het om een economische transactie tussen twee gelijkwaardige partijen. In de zorg gaat het om een morele relatie tussen twee ongelijkwaardige partijen. Wijsgerig geformuleerd: de markt is economisch gekwalificeerd en de zorg is moreel gekwalificeerd. Natuurlijk spelen in de gezondheidszorg economische mechanismen een belangrijke rol en die rol zal in de toekomst nog belangrijker worden.

3. Sacralisering van het vitale leven. In onze samenleving is gezondheid een groot goed geworden. Alles draait om perfectie: in onze lichamelijke verschijning, ons psychisch functioneren, onze sociale relaties en onze spirituele ontwikkeling. Elke afwijking van dit perfecte beeld is ongewenst, wordt 'medisch' geduid en dient door de gezondheidszorg opgelost te worden. Dit mechanisme komt bijvoorbeeld scherp naar voren in de documentaire Beperkt houdbaar van Sunny Bergman. Hans Achterhuis heeft er terecht op gewezen dat deze trend utopische trekken heeft. Hij spreekt dan ook over een 'gezondheidsutopie'.58 Het ideaal van perfectie heeft als 'logisch' gevolg dat veel chronisch zieken, gehandicapten en ouderen moeite hebben met vragen rond welzijn en zingeving. Hun leven is niet perfect en ze takelen langzaam maar zeker af. Voor hen is geen plaats in het 'nieuwe Jeruzalem van de perfecte mens'.

4. Sacralisering van het individu. In het verlengde van de sacralisering van het vitale leven vindt een sacralisering van het individu plaats. Het gaat om authenticiteit en zelfexpressie. De postmoderne mens geeft vorm aan zijn of haar eigen leven: lichaam, emoties, relaties en spirituele ontwikkeling. Het eigen leven wordt het onderwerp van keuze en calculatie. In Second Life is dit al op virtuele wijze mogelijk. Het behoeft geen toelichting dat deze ontwikkeling een geweldig beslag legt op 
het individu: het vraagt veel energie om jezelf vorm te geven zonder op reeds aanwezige patronen te kunnen of willen terugvallen. En deze ontwikkelingen hebben forse consequenties voor de samenleving: het is bijzonder moeilijk om vanuit al 'vormgegeven individuele levens' nog tot een 'wij' of een 'samenleving' te komen. ${ }^{59}$

Als deze fenomenen een eerste karakteristiek geven van de gezondheidszorg in onze samenleving - een systeem dat in vergelijking met andere landen de toets der kritiek op het gebied van kwaliteit en kosten goed kan doorstaan - dan zal duidelijk zijn dat dit systeem op de lange termijn niet duurzaam is. Het zal steeds moeilijker worden om de stijgende kosten op te brengen en om goed met de problematiek van welzijn en zingeving om te gaan. De reden daarvoor is dat de verschillende fenomenen op gespannen voet met elkaar staan, elkaar versterken en ongewenste neveneffecten hebben. Ik geef $u$ enkele voorbeelden.

Er is een geweldige spanning tussen de sacralisering van de medische wetenschap enerzijds en de sacralisering van het individu anderzijds. De moderne medische wetenschap richt zich op de beheersing van het ziekteproces. Deze beheersing impliceert dat de patiënt een object van medisch handelen wordt. Het moderne individu wil echter zijn eigen leven vormgeven en wil zich door niets en niemand laten beheersen. Deze spanning wordt door de verschillende patiëntenbewegingen haarscherp aangevoeld. We hebben hier te maken met wat Dooyeweerd de spanning tussen het wetenschapsideaal en het vrijheidsideaal zou noemen (zie paragraaf 3.3). Ook is er een spanning tussen de sacralisering van het vitale leven en de sacralisering van het individu. De idealen rond perfectie maken het bijzonder moeilijk om in positieve termen te spreken over chronisch zieken, medemensen met een lichamelijke of verstandelijke handicap en ouderen die 'aftakelen'. De samenleving beoordeelt hen naar hun afwijking van het ideaal. Alles wat ze te geven hebben - en: zinvol leven heeft toch ook te maken met geven! - verdwijnt achter de afwijking of beperking. De medische wetenschap reduceert hen tot hun ziekte of tot hun aandoening. Daar wordt alle aandacht op gericht en er is weinig aandacht voor datgene wat ze nog wel kunnen. Het zal duidelijk zijn dat deze spanning sterk bijdraagt aan de problematiek van welzijn en zingeving. 
Maar de verschillende fenomenen versterken elkaar ook. Als we al ons heil van de medische wetenschap verwachten zal de problematiek rond welzijn en zingeving nieuwe zorgvragen oproepen. De markt zal op deze nieuwe zorgvragen inspelen door nieuwe 'producten'te ontwikkelen. Het is maar de vraag in hoeverre een (post-)moderne gezondheidszorg dit soort problemen kan oplossen. Ligt hier niet juist een taak voor de nietmedische zorg: de netwerken waarin mensen leven, de kerken waar ze lid van zijn of de humanistische gesprekgroepen waarvan ze deel uit maken? Rutger Jan van der Gaag - hoogleraar klinische- en jeugdpsychiatrie formuleert dit in een recent interview als volgt: 'Mensen worden niet het beste geholpen door een psychiater of een therapeut. Het zijn de gewone menselijke dingen, van de mensen om hen heen, die het belangrijkste zijn.' ${ }^{60}$ Een verbond van medische wetenschap en markt zal naar verwachting leiden tot een verhoging van de kosten, zonder dat de vragen rond welzijn en zingeving daadwerkelijk worden opgelost. Een tweede voorbeeld. Als het gaat om het 'perfecte leven', als elk individu 'zijn of haar eigen leven wil vormgeven' dan zal dit leiden tot allerlei nieuwe zorgvragen. Ook nu zal de markt op deze zorgvragen inspelen door een veelheid van producten aan te bieden die aan de wensen van de vrager voldoen. Ook zal de markt ervoor zorgen dat consumenten 'uitgenodigd' worden - beter: sociale druk zullen ervaren - om van al die mogelijkheden gebruik te maken. Het is de vraag of we deze richting uit moeten. Dragen dit soort ontwikkelingen werkelijk bij tot welzijn van individuen en van de samenleving? Vormen ze werkelijk de sleutel tot een zinvol leven? Sunny Bergman maakt in haar al genoemde documentaire Beperkt houdbaar pijnlijk zichtbaar hoe een 'sacrale markt' de onzekerheid van meisjes en vrouwen exploiteert.

Ten slotte wijs ik op enkele neveneffecten. Allereerst moet erkend worden dat in een aantal gevallen 'marktwerking' in de zorg leidt tot een verbetering van de kwaliteit van de zorg én tot een verlaging van de kosten. Maar we moeten beseffen dat hetzelfde marktmechanisme leidt tot de creatie van nieuwe markten, tot maximalisatie van het aantal verrichtingen (omzet) en tot maximalisatie van het inkomen van enkele geprivilegieerde groepen. Het is de vraag of deze neveneffecten opwegen tegen de veronderstelde of gerealiseerde voordelen. Daarnaast leidt de nadruk op het individu tot 'dunnere' sociale relaties en 'zwakkere' sociale netwerken. Het gevolg is dat het vermogen van de omgeving om te zorgen afneemt, het beroep op de medische zorg toeneemt en de welzijns- en zingevingsproblematiek verergert. 
Mocht deze analyse juist zijn, dan zullen we - mede met het oog op de demografische ontwikkelingen - het moderne en postmoderne heilige moeten problematiseren. Dan zullen we - als we de analyses van Szerszynski, Ferry en Dooyeweerd serieus nemen - aandacht moeten geven aan transcendentie die pluraliteit mogelijk maakt (Szerszynski), aan immanente transcendentie (Ferry) en aan christelijke transcendentie (Dooyeweerd). Dan zullen we moeten werken aan herstel van symmetrie (medische zorg versus niet-medische zorg, arts versus patiënt, gezond versus ziek, enzovoorts), aan een dialoog over waarden die verschil maken en aan het versterken van de samenhang in onze samenleving. ${ }^{61}$

\section{Het sacrale in innovatie: een casus in de gezondheidszorg}

De voorgaande beschouwingen hebben in hoge mate een theoretisch karakter, met alle voordelen en beperkingen van dien. Ik wil proberen om deze thematiek verder te verhelderen, te nuanceren en aan te scherpen door een casus uit de Nederlandse gezondheidszorg. Het betreft een innovatie in een psychiatrisch ziekenhuis. Er zijn twee redenen om deze casus naar voren te brengen. Allereerst, ken ik de casus van binnenuit. Als directeur heb ik leiding mogen geven aan de invoering van deze innovatie. Daarnaast zijn er veel patiënten in de psychiatrie die niet voldoen aan het beeld van het moderne en postmoderne heilige. Zij zijn niet autonoom en kunnen hun eigen leven nauwelijks vorm geven. Zij zijn sterk afhankelijk van anderen en hebben al hun energie nodig om 'staande te blijven' in het leven. En juist in die afhankelijkheid komt hun welzijns- en zingevingsproblematiek scherp naar voren.

\subsection{De innovatie: zorgprogramma's}

In januari 2003 werd ik benoemd als divisiemanager van het psychiatrisch ziekenhuis Vijverdal in Maastricht. Ruim anderhalf jaar later kreeg ik de leiding over de gehele organisatie. In die tijd had Vijverdal 350 bedden voor de opname van psychiatrische patiënten, 64 stoelen voor deeltijdbehandeling en waren er circa 23.000 face-to-face contacten met ambulante patiënten. Het ziekenhuis kende veel specialisaties. De activiteiten waren over een groot aantal organisatorische eenheden verdeeld: er waren tien tot twaalf klinische afdelingen, circa vijf 
deeltijdgroepen en ongeveer tien verschillende poli's. Mijn opdracht was het reorganiseren van het ziekenhuis, het oplossen van de financiële problemen, het implementeren van enkele innovaties en het veilig stellen van de strategische positie op lange termijn. Ik wil me in deze oratie beperken tot één van de belangrijkste innovaties: het implementeren van zorgprogramma's.

In de periode 2000 - 2002 groeide het besef dat de zorg op een andere manier georganiseerd zou moeten worden. Een intern rapport constateerde de volgende problemen:

- ontbreken van continuïteit van de zorg;

- slechte samenwerking tussen de verschillende professionals •

- binnen en buiten de kliniek;

- onbeheersbaarheid van de patiëntenlogistiek;

- afwezigheid van goede behandelprogramma's;

- tekort aan behandelcapaciteit;

- en het onvermogen om te reageren op de individuele wensen van patiënten.

Er werd voorgesteld om de functionele eenheden af te breken en de zorg in zogenaamde zorgprogramma's of 'clinical pathways' onder te brengen. De kern van een zorgprogramma is dat alle soorten zorg die een patiënt nodig heeft in een zorginhoudelijke en logistieke eenheid zijn ondergebracht.Injuni 2001 werden door de gezamenlijkezorginstellingen (Vijverdal, azM, Riagg en RIBW) enkele werkgroepen ingesteld die deze zorgprogramma's zouden definiëren en de organisatorische randvoorwaarden zouden bepalen. Vanaf het begin was duidelijk dat deze zorgprogramma's alleen gerealiseerd zouden kunnen worden als de verschillende zorginstellingen in de regio Maastricht hun specialismen zouden bundelen. Eind 2002 werd een rapport uitgebracht onder de titel Zorgprogramma's in de regio Heuvelland, Maastricht \& Westelijke Mijnstreek waarin de verschillende zorgprogramma's werden voorgesteld en beschreven. ${ }^{62}$ Dit rapport was samengesteld door professionals uit de verschillende zorginstellingen en werd breed gedragen. De raden van bestuur van genoemde instellingen onderschreven het rapport en de aanbevelingen. Zij stimuleerden hun medewerkers om samen te werken 'alsof de zorgprogramma's al volledig geïmplementeerd waren'. Echter, de raden van bestuur konden het niet eens worden over de financiële, organisatorische en veranderkundige condities. Met als gevolg dat ondanks alle goede wil van de zorgprofessionals - de zorgprogramma's niet van de grond kwamen. 
In augustus 2003 besloot het management team van Vijverdal om binnen het eigen ziekenhuis de verschillende zorgprogramma's zoveel mogelijk te implementeren. Dit was ook mogelijk omdat Vijverdal de belangrijkste ingrediënten van deze programma's zelf in huis had (kliniek, deeltijdbehandeling, poli's). Daarnaast zou dit een mooie voorbereiding zijn voor de regio-brede invoering. De volgende programma's zouden in Vijverdal ingevoerd worden:
[a] nieuwe patiënten (voordeur);
[b] angststoornissen;
[c] stemmingsstoornissen;
[d] persoonlijkheidsstoornissen;
[e] niet-aangeboren hersenletsel;
[f] ouderenpsychiatrie;
[g] en psychotische stoornissen (langdurige zorg).

In een periode van ruim twee jaar werden de zorgprogramma's in Vijverdal ingevoerd. In een dialogisch proces tussen management, professionals en ondersteuning werd het 'hoe' van de invoering van de zorgprogramma's besproken, de verschillende alternatieven afgewogen, de noodzakelijke besluiten genomen en ten slotte werden de plannen uitgevoerd. Dit proces verliep bijzonder voorspoedig: er was nauwelijks weerstand in de organisatie en de cliëntenraad en ondernemingsraad stelden zich kritisch maar constructief op.

\subsection{Interpretatie van de innovatie}

Hoe moeten we deze innovatie precies begrijpen? Waarom waren er nauwelijks debatten over de fundamentele uitgangspunten? Waarom trokken management en zorgprofessionals gezamenlijk op? Waarom verliep de invoering gesmeerd? In paragraaf 2 heb ik laten zien dat een muziekstuk begrepen kan worden door aandacht te richten op de muziekpraktijk. In het bijzonder door de analyse van drie verschillende perspectieven: structuur van de compositie, de intenties van de componist, en de context waarin deze muziek ten gehore wordt gebracht. Zouden we de implementatie van zorgprogramma's in de psychiatrie kunnen interpreteren door onze aandacht te richten op de zorgpraktijk? Zouden de drie genoemde perspectieven essentiële elementen van die innovatie kunnen doen oplichten? 
1. Structuur van de zorgpraktijk. Het begrip 'structuur' verwijst naar de 'formele' aspecten van de organisatie. We denken hierbij aan (a) de organisatiestructuur en het kwaliteitssysteem van de organisatie, (b) de voorschriften, richtlijnen en protocollen van het zorgproces, en (c) de hulp- en stafafdelingen. De implementatie van de zorgprogramma's leidde tot een mega change in de structuur van de organisatie. Als eerste, de gehele organisatiestructuur veranderde. De verschillende klinieken, deeltijdafdelingen en poli's werden in een zevental zorgprogramma's ondergebracht. Elk zorgprogramma richtte zich op één stoornis of een familie van stoornissen en bevatte in principe een eigen poli, deeltijdafdeling en kliniek. ${ }^{63}$ Elk zorgprogramma was een zorginhoudelijke, organisatorische en financiële eenheid en stond onder leiding van een zorgmanager (zorginhoud) en een lijnmanager (organisatie, financiën). Ten tweede, het zorgproces veranderde sterk: de zorg werd als zorgprogramma aangeboden. Met als gevolg dat alleen modules en behandelmethoden die in dit programma aanwezig waren, aangeboden mochten worden. Daarnaast - en hier komt het principe van continuiteit van de zorg naar voren - omvatte het behandelplan alle benodigde modules en bleef de hoofdbehandelaar verantwoordelijk voor de zorg van de patiënt, onafhankelijk waar deze zich bevond (poli, deeltijd, of kliniek). In de derde plaats moesten de hulp- en stafafdelingen zich anders organiseren om aan de zorgprogramma's de benodigde service te leveren. De lijnmanager maakte met de verschillende afdelingen afspraken welke services tegen welke prijs geleverd werden. Samenvattend, het begrip 'structuur' geeft een goed inzicht in het hoe en wat van de innovatie.

2. Intenties van professionals en managers. In enkele belangrijke documenten werd de continuïteit van de zorg als belangrijke motivatie genoemd om de zorgprogramma's in te voeren. Maar verder was er weinig bekend over de intenties van de verschillende professionals en managers. Om hierin meer inzicht te krijgen heb ik samen met enkele studenten ongeveer driekwart van het managementteam geïnterviewd: drie managers, drie zorgprofessionals en twee hoofden van ondersteunende diensten. We hebben daarbij gebruik gemaakt van de zogenaamde life story interview. Deze methodiek wordt door Atkinson omschreven als een 'fairly complete narrating of one's entire experience of life as a whole, highlighting the most important aspects'. ${ }^{64}$ Levensverhalen zijn van groot belang voor de wetenschap omdat ze inzicht geven in hoe de geïnterviewde zichzelf ziet, zich verhoudt tot anderen, de zin van het leven ervaart en de gehele werkelijkheid interpreteert. 
Elk interview duurde anderhalf tot twee uur. Het interview werd met een recorder opgenomen, de tekst werd uitgewerkt, ter accordering aan de geïnterviewde voorgelegd en door middel van open en axial coding geanalyseerd. ${ }^{65}$ De geïnterviewden kwamen uit verschillende milieus: protestant, katholiek, humanistisch en 'neutraal'. Uit de eerste analyse van de interviews blijkt dat life stories cruciaal zijn om de inzet van de professionals en managers in dit innovatietraject te begrijpen. Ik geef drie voorbeelden.

Manager A is bijzonder gemotiveerd door de houding van zijn ouders. Hij vertelde dat zijn ouders kerkelijk en maatschappelijk zeer actief waren. Hij zegt dat hij tijdens zijn jeugd een sterk gevoel voor 'rechtvaardigheid' heeft meegekregen: 'Maar steeds speelde dus dat er doorheen van opkomen voor mensen die onderdrukt worden, opkomen voor mensen die maatschappelijk uitgestoten worden, opkomen voor mensen die door de geldingsdrang van anderen eigenlijk niet ten volle tot bloei komen. Dat is eigenlijk de essentie.'Tijdens zijn opleiding in de psychiatrie keert hij zich tegen de trend om vooral aandacht te geven aan de psychische problemen van de upper class. Hij is van mening dat de schaarse middelen in de zorg vooral ingezet moeten worden voor patiënten met een ernstige en chronische psychiatrische problematiek. In zijn visie is de belangrijkste taak van de hulpverlening de 'maatschappelijke uitsluiting door psychiatrische problematiek maximaal terugdringen'.

De keuzen van professional B worden in hoge mate bepaald door de vorming in zijn jonge jaren. Hij is opgevoed in een omgeving met 'christelijke waarden en normen' terwijl het gezin waar hij uitkwam een meer 'humanistische oriëntatie' had. Belangrijke waarden die hij heeft meegekregen zijn 'je moet het beste er van maken' en 'je moet voor jezelf zorgen'. Ook heeft hij leren omgaan met mensen met een handicap. Hij kiest nadrukkelijk voor de zorgprogramma's omdat deze innovatie recht doet aan zowel de medische als de sociale aspecten van 'severe mental illness'. Ook omdat deze innovatie mensen ondersteunt om zoveel mogelijk zelfstandig door het leven te gaan:'Een van de valkuilen van ons vak is dat je vraagt vooral "wat gaat er niet goed, wat zijn de klachten, wat zijn de problemen". En die moet je natuurlijk ook weten en daar moet je wat mee doen. Maar bij mensen met langdurige beperkingen moet je het eigenlijk hebben van de dingen die goed gaan ... Het is vooral focussen op wat mensen nog wel kunnen en proberen dat te versterken.' 
Professional C vindt het belangrijk dat innovaties mede worden vormgegeven door humanistische waarden. Hij is opgevoed in een humanistisch milieu en heeft als dominante waarde 'respect voor anderen' meegekregen. Tijdens het interview wordt het woord respect vaak gebruikt: zowel ten opzichte van collega's en management als met betrekking tot patiënten. Tijdens de implementatie heeft hij geweldig veel werk verzet om consensus te bereiken over ideologische verschillen tussen zorgprofessionals. Over het oplossen van zo'n diepgaand meningsverschil zegt hij: 'Uiteindelijk hebben ze dat voor een groot deel zelf gedaan, want ze voelden zich serieus genomen. Ze werden ook met elkaar in gesprek gebracht en niet meer alleen maar om notities te schrijven die vervolgens in de la gingen ... Maar je ging gezamenlijk de discussie aan met respect voor elkaar. En dan kunnen de dingen gezegd worden die je moet zeggen. We moesten wel, we konden niet anders, en dat heeft mij gemotiveerd om op die weg door te gaan.'

Samengevat, deze eerste analyse laat zien dat intenties en diepste overtuigingen een belangrijke rol spelen in de innovatie in de geestelijke gezondheidszorg. Het managementteam dat leiding gaf aan deze innovatie vertoonde alle karakteristieken van een postmodern pallet: grote verschillen in levenbeschouwelijke oriëntering. Maar deze grote verschillen bleken niet te leiden tot grote verschillen in de praktijk van de innovatie. Allereerst deelden de deelnemers de opvatting dat waarden niet subjectief zijn maar een zeker universeel karakter hebben. Daarnaast bleken de verschillende intenties en waardepatronen zekere 'familiegelijkenissen' te vertonen (Wittgenstein) en is er sprake van 'overlappende consensus'(Taylor).

3. De context van de innovatie. In de casus Vijverdal speelden nationale invloeden een grote rol. Ik denk onder andere aan de druk om evidence based behandelingen te gebruiken, kwaliteitsindicatoren te ontwikkelen, de performance van de zorg te meten, als marktspeler te opereren, het EPD en de DBC's te implementeren, enzovoorts. Maar lokale invloeden waren van groot belang. Als eerste, de bijzondere geschiedenis van Vijverdal die gekenmerkt werd door bestuurlijke crises, financiële problemen en zorginhoudelijke doorbraken - leidde tot een complexe relatie met de zorgverzekeraar. Daarnaast was er een lange geschiedenis van fusies, defusies, samenwerkingen en verbroken relaties tussen de verschillende zorginstellingen in de regio. Ondanks die geschiedenis spanden de verschillende zorginstellingen zich in om intensief samen te werken en 
elke patiënt die zorg te geven die hij of zij nodig had. Deze inspanning vroeg bijzonder veel energie omdat de 'chemie' tussen de verschillende raden van bestuur 'complex' was. Deze contextuele invloeden hadden een grote invloed op het innovatieproces in Vijverdal.

Ik concludeer dat de analyse van innovaties in de zorg vanuit de perspectieven 'structuur', 'intenties' en 'context' een dieper inzicht geeft in de keuze voor zorgprogramma's, de vormgeving van zorgprogramma's en de manier waarop deze zorgprogramma's geïmplementeerd werden.

\subsection{Het sacrale in innovatie}

In de vorige paragraaf hebben we gezien dat de intenties van professionals en managers een grote rol speelden in de innovatie in Vijverdal. Opvallend was de geweldige gedrevenheid die de verschillende zorgprofessionals, managers en ondersteunende diensten aan de dag legden om deze innovatie te implementeren. Een gedrevenheid die verder ging dan een 'professionele motivatie'. Ik geef twee voorbeelden.

Manager A zette zich volledig in voor de zorg voor patiënten met een ernstige en chronische psychiatrische problematiek. Hij had één doel voor ogen: het invoeren van zorgprogrammering voor deze doelgroep. Dat betekende de invoering van de methodieken assertive community treatment en rehabilitation. Door alle bezuinigingen en reorganisaties heen bleef hij aan dat doel vasthouden. Door een combinatie van professionele overtuigingskracht, samenwerkingsgerichtheid en managementmacht wilde hij de maatschappelijke uitsluiting van mensen met een psychiatrische problematiek maximaal kunnen terugdringen.

Professional C zette zich ook met hart en ziel in voor de samenwerking tussen de verschillende zorginstellingen ten behoeve van de zorgprogramma's. Op een kritisch moment in dit proces heeft hij - op een zondagmorgen op de fiets - een brief gebracht naar de verschillende raden van bestuur waarin hij zijn ongenoegen uitte over de stagnatie in het samenwerkingsproces. Deze brief deelde niet alleen aan de betrokken bestuurders (en aan zijn eigen baas) een 'brevet van onvermogen' uit maar was ook een 'motie van wantrouwen'. Hij 'kon niet anders'. En hij zou de eventuele consequenties dragen. 
Deze twee voorbeelden laten zien dat diepste overtuigingen met betrekking tot mens en samenleving vormgeven aan iemands professionele en leidinggevende handelen. Ze laten zien waarom iemand wil innoveren en waarom welke innovaties gekozen wordt. Ze verklaren waarom innovaties op een bepaalde manier ontwikkeld en geïmplementeerd worden en maken duidelijk waarom iemand forse offers wil brengen. We stuiten hier op een 'sacrale' of 'heilige' kern van de key actors in dit innovatieproces in de zorg. We stuiten hier op een kern die verklaart waarom deze innovatie een succes werd.

\subsection{Theoretische modellen}

In paragraaf 2 heb ik drie perspectieven gebruikt om Diptyque pour orgue van Olivier Messiaen te begrijpen: de compositie, de intenties en diepste overtuigingen van de componist, en de context waarin de muziek wordt gemaakt en beluisterd. Deze drie perspectieven heb ik vervolgens in paragraaf 5.2 gebruikt om meer inzicht te krijgen in een zorginnovatie in de gezondheidszorg. We hebben gezien dat zowel de zorginhoudelijke, organisatiekundige als contextuele elementen van deze innovatie scherp naar voren kwamen. Ook hebben we gezien dat de diepste intenties en overtuigingen van de key actors van doorslaggevende betekenis waren in het succes van deze innovatie. De benadering die ik spelenderwijs heb geïntroduceerd is gebaseerd op twee pijlers. Allereerst het praktijkbegrip zoals ontwikkeld door de Britse filosoof Alasdair Maclntyre in zijn beroemde boek After Virtue. ${ }^{66}$ Daarnaast is gebruikgemaakt van enkele begrippen en onderscheidingen uit de christelijke wijsbegeerte. In het bijzonder het onderscheid tussen structuur, richting en context zoals voorgesteld Dirk Vollenhoven, Richard Mouw en Sander Griffioen. ${ }^{67}$ Deze benadering - die ook wel het Normative Practice Model is genoemd - is verder uitgewerkt voor zorgpraktijken door Henk Jochemsen en Gerrit Glas, en voor technische praktijken door Maarten Verkerk, Jan Hoogland, Jan van der Stoep en Marc de Vries. ${ }^{68}$ 
Hoe verhoudt deze benadering zich tot de verschillende modellen in de literatuur? We geven allereerst een overzicht van de verschillende benaderingen, kernbegrippen en foci69:

[1] SCOT-benadering: Social Construction of Technology. De boodschap van deze benadering is dat technologie geen neutrale of waardevrije kracht is waar de samenleving op reageert maar dat sociale processen een belangrijke rol spelen in het ontwerp en de implementatie van technologieën. Eén van de grondleggers van deze stroming is collega Wiebe Bijker van deze faculteit. Belangrijke begrippen in deze benadering zijn: relevante sociale groepen, interpretatieve flexibiliteit, technologisch kader en macht. ${ }^{\circ}$ Deze benadering kan samengevat worden met de slogan 'follow the artefact'.

[2] ANT-benadering: Actor Network Theory. In deze benadering wordt benadrukt dat de ontwikkeling van artefacten of systemen in netwerken plaatsvindt van menselijke en niet-menselijke actoren. Belangrijke begrippen zijn: co-constructie, menselijke actoren, niet-menselijke actoren, netwerk en translatie. ${ }^{71}$ De kern van deze benadering kan uitgedrukt worden met 'follow the actors'.

[3] TiP-benadering: Technology in Practice. In deze benadering gaat er vanuit dat verschillende professionele praktijken met elkaar interacteren. Belangrijke begrippen zijn: professionele praktijk, inbedding, representatie van de gebruiker, en interactie tussen mens en artefact..$^{22}$ Deze benadering kan gekarakteriseerd worden als 'follow the practice'.

[4] WCI-benadering: Walls and Ceilings in Innovation. In deze benadering wordt gesteld dat innovatie in de gezondheidszorg in hoge mate bepaald wordt door 'muren' tussen de verschillende interventies in het primaire proces en door 'plafonds' tussen de verschillende hiërarchische niveaus binnen een organisatie en tussen een organisatie en zijn omgeving. ${ }^{73}$ De kern van deze benadering ligt in het 'follow the change process'. 
En als we de hierboven gebruikte benadering op dezelfde manier zouden samenvatten, dan komen we tot:

[5] NPM-benadering: Normative Practice Model. In deze benadering wordt benadrukt dat innovatie in professionele praktijken plaatsvindt. Belangrijke begrippen zijn: professionele praktijk, structuur (constitutieve regels), richting (regulatieve overtuigingen) en context (omstandigheden). ${ }^{74}$ Deze benadering kan ook gekenmerkt worden als 'follow the practice'.

Ik maak enkele opmerkingen. In de eerste plaats, de bovenstaande benaderingen hebben veel met elkaar gemeen. Ze zijn geworteld in de overtuiging dat het ontwikkelen en implementeren van innovaties in de gezondheidszorg bijzonder complex is en dat een bepaald perspectief nodig is om de complexiteit van innovatie te kunnen begrijpen. Daarnaast delen ze de opvatting dat (filosofische) reflectie zich in nauwe relatie met de praktijk moet ontwikkelen ('empirical turn'). In de tweede plaats, elke benadering kan gezien worden als een 'bril' die verschillende aspecten van het gehele innovatieproces laat oplichten. Daarom is het vruchtbaarder om te denken in termen van een 'familie van benaderingen' die elkaar aanvullen, dan om te spreken over concurrerende benaderingen waartussen gekozen moet worden. In de derde plaats, er zijn grote verschillen in de onderliggende visie op mens en werkelijkheid. In het bijzonder onderscheidt het normatieve praktijkmodel zich op enkele aspecten. Dit model benadrukt de verschillende normatieve momenten van de structuur van een zorgpraktijk, zoals zorgverlening, management en ondersteuning. Daarnaast geeft dit model expliciet aandacht aan de intenties en diepste overtuigingen van menselijke actoren als eigensoortige kracht die niet gereduceerd kan worden tot sociale of economische factoren. Erik Borgman drukt deze twee elementen - normatieve momenten en diepste overtuigingen - mooi uit in de woorden 'waardegeladen en waardeontvangende praktijk'.75 In de laatste plaats merk ik op dat er in de literatuur weinig aandacht is voor de invloed van intenties en diepste overtuigingen van actoren op het innovatieproces. ${ }^{76}$ In de organisatiekunde is de relatie tussen de werkplek, organisatie, verbondenheid en spiritualiteit wel een belangrijk thema. ${ }^{77}$ Deze 'witte vlek' in het onderzoeksveld van 'innovatieculturen' is een van mijn onderzoekslijnen. 


\section{Onderzoeksprogramma}

De bovengenoemde casus geeft een blik op het onderzoek dat ik aan de Universiteit Maastricht verricht. Daarnaast doe ik aan de Technische Universiteit Eindhoven onderzoek op het gebied van de ethiek en de filosofie van techniek. Ik werk aan twee hoofdonderwerpen die nauw op elkaar aansluiten:

1. Ethiek, techniek en organisatie (TUE)

In de groep van professor Meijers verricht ik met Lambèr Royakkers (TUE) onderzoek op het gebied van ethiek van management en organisatie en met Andreas Spahn op het gebied van de ethiek van duurzaamheid.

2. Religie, innovatie en organisatie

In de groep van professor Bijker doe ik onderzoek naar de relatie tussen religie en innovatie in de gezondheidszorg. Kort gezegd, het gaat om de 'religieuze constructie' van innovaties. Samen met professor Den Hertog van de Faculteit voor Economische Wetenschappen en Bedrijfskunde doe ik onderzoek naar (de ethiek van) het managen van innovatie.

Als onderdeel van mijn werk begeleid ik als eerste of tweede promotor enkele promovendi:

- Wout Penning werkt aan een proefschrift op het gebied van levensbeschouwelijk onderwijs en burgerschap (TUE).

- Eelco van den Dool werkt aan een proefschrift op het gebied van spiritualiteit en innovatie (UM).

- Michiel van Well werkt aan een proefschrift op het gebied van de invloed van religie op innovatie in de gezondheidszorg (UM).

- $\mathrm{Er}$ is een promotieplaats voor onderzoek naar het ontwerpen en implementeren van een gezondheidsmonitor voor geestelijk gehandicapten (UM). 


\section{Samenvatting en conclusies}

In mijn rede heb ik geprobeerd om de relatie tussen cultuur, wetenschap en religie te onderzoeken aan de hand van de begrippen 'sacraal' en 'seculier'.Allereerst hebben we gezien dat de betekenis van deze begrippen in loop van de geschiedenis radicaal veranderd zijn. Szerszynski spreekt over de 'lange boog van de transcendentale religie', Ferry over 'radicale breuken in de cultuur' en Dooyeweerd over de 'drijvende kracht van grondmotieven'. Daarna heb ik de vraag naar het sacrale in de moderne gezondheidszorg aan de orde gesteld. We zijn op vier fenomenen gestuit: sacralisering van de medische wetenschap, sacralisering van de markt, sacralisering van het vitale leven en sacralisering van het individu. Ten slotte hebben we geprobeerd om de relatie tussen religie, ethiek en zorginnovatie te verkennen aan de hand van een casus: de implementatie van zorgprogramma's in de psychiatrie. Deze casus maakte duidelijk dat religieuze motieven van doorslaggevende betekenis kunnen zijn in de ontwikkeling en implementatie van een innovatie.

Ik kom tot de volgende conclusies:

[1] Szerszynski, Ferry en Dooyeweerd laten zien dat de relatie tussen het sacrale en seculiere in de geschiedenis van onze cultuur bijzonder complex is. Uit hun analyse blijkt dat de moderniteit niet gekenmerkt kan worden als 'onttovering' van de werkelijkheid maar dat er sprake is van een 'herordening van het sacrale'.

[2] Szerszynski, Ferry en Dooyeweerd maken aannemelijk dat elke opvatting over de relatie tussen het sacrale en het seculiere uiteindelijk wordt bepaald door de visie op de orde in de werkelijkheid: onpersoonlijke kosmische orde (het Griekse denken), persoonlijke scheppingsorde (het christelijke denken), zelf-ordenende mens (de moderniteit) en botsende krachten en driften (Nietzsche).

[3] De moderne gezondheidszorg wordt gekenmerkt door vier sacrale momenten: de medische wetenschap, de markt, het vitale leven en het individu. Deze momenten staan met elkaar op gespannen voet, ze versterken elkaar en ze hebben ongewenste neveneffecten.

[4] De uitdagingen van de gezondheidszorg (dubbele vergrijzing, welzijn en zingeving) vragen om een problematisering van het sacrale in onze cultuur. We zullen aandacht moeten geven aan transcendentie, aan herstel van symmetrie en aan het versterken van de samenhang in de samenleving. 
[5] Empirisch onderzoek in de psychiatrie laat zien dat religie een grote invloed heeft op de ontwikkeling en implementatie van innovaties. Ik heb laten zien dat de diepste overtuigingen van de key actors een groot effect hebben op de beslissing om te innoveren, de keuze tot een bepaalde innovatie, op het vormgeven en implementeren van die innovatie en op de inspanningen (offers) om een bepaalde implementatie te realiseren.

[6] $\mathrm{Er}$ is in de literatuur een familie van benaderingen of modellen aanwezig die bepaalde elementen van het innovatieproces belichten. Het normatieve praktijkmodel, zoals dat door een aantal christelijke filosofen is ontwikkeld, besteedt in het bijzonder aandacht aan de verschillende normatieve momenten zoals deze zich voordoen tijdens de ontwikkeling en implementatie van een zorginnovatie, en aan de intenties en de diepste overtuigingen van menselijke actoren. 


\section{Dankwoord}

Aan het einde van deze rede wil ik graag enkele woorden van dank uitspreken.

Allereerst gaat mijn dank uit naar het bestuur en de curatoren van de Vereniging en de Stichting voor Reformatorische Wijsbegeerte. Ik ben $\mathrm{u}$ zeer erkentelijk voor het in mij gestelde vertrouwen. Ik hoop - refererend aan de vraag waarmee ik ben begonnen - dat u uit mijn rede geproefd hebt dat een calvinist zich bijzonder goed thuis kan voelen aan seculiere universiteit in het roomse Zuiden. Maar ik hoop bovenal aannemelijk te hebben gemaakt dat dit een bijzonder mooie positie is om begrippen als sacraal en seculier vanuit de humanistische en de christelijke traditie te problematiseren en zo een bijdrage te leveren aan actuele filosofische en maatschappelijke debatten.

Ik dank de Universiteit Maastricht en de Faculteit Cultuur- en Maatschappijwetenschappen voor de goedkeuring die zij aan deze benoeming hebben gegeven. Ik besef dat het niet vanzelfsprekend is dat dit soort leerstoelen worden ingesteld. In de gesprekken rond mijn benoeming is de verwachting uitgesproken dat het kruispunt van de Maastrichtse onderzoekstraditie (SCOT), de reformatorische techniekfilosofie en het kennisgebied van management en organisatie wel eens bijzonder vruchtbaar zou kunnen zijn. Ik hoop dat ik met deze rede heb laten zien dat er op dit kruispunt allerlei spannende vragen liggen en dat de begrippen en visies die in de christelijk-wijsgerige traditie ontwikkeld zijn, kunnen leiden tot nieuwe perspectieven en inzichten. Ik dank in het bijzonder Rein de Wilde, decaan van de faculteit, Sjaak Koenis, hoofd van de vakgroep filosofie, Wiebe Bijker, hoofd van het onderzoeksprogramma Science and Technology Studies, Jaap Hoogenboezem, mijn kamergenoot, en de leden van de faculteit voor de hartelijke ontvangst. Ik hoop dat we vruchtbaar met elkaar mogen samenwerken.

Ik wil de studenten bedanken voor hun inzet en enthousiasme. Het afgelopen jaar heb ik met enkelen van u mogen discussiëren over politieke filosofie, christelijke wijsbegeerte en innovatie in de zorg. Ook heb ik met de studentenverenigingen Ichthus, de Navigators en de studentenekklesia Tafelstraat 13 al een goede band mogen opbouwen. 
Ik dank al die mensen die bijgedragen hebben aan mijn academische vorming. Als eerste wil ik Jan Dengerink danken die mij enthousiast heeft gemaakt voor de christelijke filosofie. Als tweede wil ik Friso den Hertog en Egbert Schuurman noemen die mij gestimuleerd hebben om mijn academische vorming af te ronden met een tweede proefschrift op het grensgebied van techniek, organisatie, ethiek en filosofie. Met veel plezier denk ik terug op jullie begeleiding. Tenslotte wil ik mijn collega-hoogleraren reformatorische wijsbegeerte - Henk Geertsema, Gerrit Glas, Jan Hoogland, Henk Jochemsen, Roel Kuiper en Marc de Vries - danken voor de prettige samenwerking en de intensieve filosofische discussies die wij met elkaar mochten hebben. In dit verband wil ik ook Sander Griffioen en Bob Goudzwaard danken die mij meer beïnvloed hebben dan ze misschien zelf beseffen.

Ik dank mijn familie, medewerkers van het centrum, leden van de kerkelijke gemeente, buren en vrienden voor alles wat jullie voor mij betekend hebben en nog steeds voor mij betekenen. Ik dank ook mijn ex-collega's voor de manier waarop we samen leiding hebben gegeven aan de innovatie in Vijverdal en voor de diepte-interviews die ik met jullie mocht hebben. Ik dank mijn collega's van VitaValley en Noaber en de partners van ons netwerk voor alles wat ik mocht leren over innovatie in de zorg en sociaal investeren.

Last but not least wil ik mijn vrouw Nienke, de kinderen Remme en Femmie, Jaapjan en Roeliene, en Marc en Marianne, en kleinkinderen Lucas en Thijs danken voor hun liefde,zorg en trouw. Ik besef steeds meer dat deze waarden in menselijke relaties niet vanzelfsprekend zijn. Steeds vaker realiseer ik me dat liefde, zorg en trouw - in de terminologie van deze oratie - transcendente waarden zijn die ik 'in genade' mag ontvangen. Dit besef maakt mij intens dankbaar en blij.

Geachte aanwezigen, ik dank $u$ allen hartelijk voor uw aandacht en aanwezigheid. Veel van wat ik heb gezegd over de 'herordening van het sacrale' en over 'religie, ethiek en zorginnovatie' zal u mogelijk vergeten. Ik hoop dat er één ding zal blijven hangen. Namelijk dat voor mij persoonlijk de kern van religie is 'aangesproken worden door' en 'antwoord geven op de roep van de Schepper'. In die aanspraak ontvangen we het 'sacrale' en mogen we dat 'sacrale' in deze 'seculiere' wereld vormgeven. Messiaen heeft in zijn enige opera die hij gecomponeerd heeft - Saint François d'Assise - laten zien dat dit aangesproken worden mensen ontvankelijk 
maakt voor het ontvangen van waarden als liefde, solidariteit, gerechtigheid en vrede; waarden die wat mij betreft leidend mogen zijn in de innovatie in de zorg.

Ik kom voor de laatste keer terug op het Diptyque pour orgue van Olivier Messiaen. De enorme contrasten en de donkere registraties van het eerste deel rekenen af met alle vormen van utopie van christelijke of humanistische huize: geen enkele zorginnovatie zal leiden tot een 'hemel op aarde'. Hoe pijnlijk ook: verdriet en leed zullen er altijd zijn. Maar de heldere klanken en de serene tonen van het tweede deel geven uitdrukking aan de christelijke hoop dat het nieuwe Jeruzalem eens uit de hemel zal neerdalen: er komt een tijd dat er geen ziekte en pijn meer zullen zijn (Openbaring 21). De melodie in mineur uit het eerste deel-die in het tweede deel in majeur terugkomt - laat zien dat de toekomst al begonnen is. Daarom is - in de woorden van Erik Borgman - de 'plaats waar we staan, heilige grond'. ${ }^{8}$

Ik heb gezegd. 


\section{Eindnoten}

$1 \quad$ Ik laat de vragen rond religie in de publieke ruimte verder liggen. Ik verwijs hiervoor naar W.B.H.J. van de Donk, A.P. Jonkers, G.J. Kronjee en R.J.J.M. Plum (red.), 2006, Geloven in het publieke domein. Verkenningen van een dubbele transformatie, Amsterdam University Press, Amsterdam en D. Loose e.a., 2007, Religie in het publieke domein. Fundament en fundamentalisme, Damon, Budel. De pleidooien voor een neutrale openbare ruimte worden onder andere gebaseerd op de zogenaamde seculariseringsthese. Deze these stelt - kort geformuleerd - dat in de loop van de geschiedenis religie vervangen is I zal worden door wetenschap. Deze these staat zowel empirisch als theoretisch ter discussie, zie Van de Donk e.a. (2006). Recent onderzoek laat zien dat Nederland (nog steeds) een 'religieus land' is. Anno 2008 rekent $58 \%$ van de volwassen bevolking zich tot een kerkgenootschap (Centraal Bureau voor de Statistiek, Religie aan het begin van de 21ste eeuw, CBS, Heerlen).

2 K. Abdolah, 2005, Het huis van de moskee, De Geus, Breda.

3 M. Hoondert, A. de Heer en J.D. van Laar (red.), 2009, Elke muziek heeft haar hemel. De religieuze betekenis van muziek, Damon, Budel.

4 R.S. Johnson geeft in zijn boek Messiaen (2008, Omnibus Press, London) een gedetailleerde analyse van de structuur van de werken van Messiaen.

5 Aangehaald uit Hoondert e.a. (2009, p38).

$6 \quad$ E. Heijerman in Hoondert e.a. (2009, p29).

7 S. van Maas, 2003, Doorbraak en idolatrie. Olivier Messiaen en het geloof in de muziek, Eburon, Delft, p7-12.

8 Hoondert in Hoondert e.a. (2009, p66).

9 Geciteerd uit Van Maas (2003, p45).

10 Een vergelijkbare gedachte wordt uitgedrukt door M. Ploeger in Hoondert e.a. (2009, p97, 98). Wijsgerig gezien is zijn formulering adequater. Hij schrijft: 'Wanneer de (gehele) werkelijkheid door een christen wordt geïnterpreteerd als een werkelijkheid die ten diepste in God rust, dan is ook de muziek te interpreteren als een onderdeel van de schepping waarin iets van de Schepper wordt geopenbaard. Niet omdat muziek iets "uitdrukt" van de religie, maar omdat de muziek (de kunst, de natuur, heel de werkelijkheid) in zichzelf uitdrukking is van God die haar Schepper is' (cursivering M.P.).

1 Geciteerd uit Van Maas (2003, p44).

12 B. Szerszynski, 2005, Nature, Technology and the Sacred, Blackwell, Malden. 


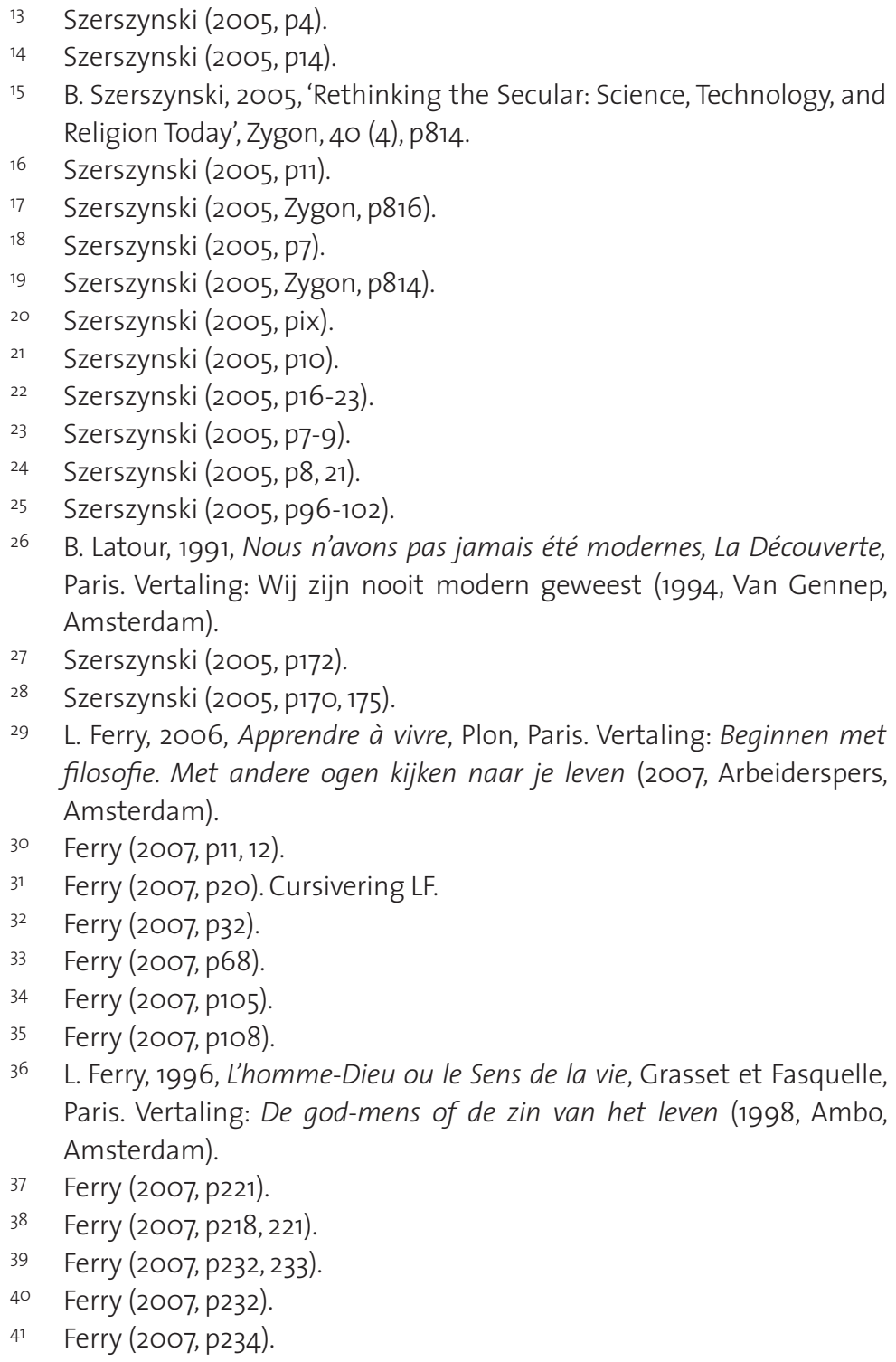


42 H. Dooyeweerd, 1963, Vernieuwing en Bezinning. Om het reformatorisch grondmotief, Van den Brink, Zutphen. Zie ook zijn artikel 'De vier religieuze grondthema's in de ontwikkelingsgang van het wijsgerig denken van het avondland', Philosophia Reformata, 1941, 6 (4), p161179. Dit artikel is ook opgenomen in het boek Herman Dooyeweerd. Grenzen van het theoretisch denken van M. Verburg (1986, Ambo, Baarn).

43 Dooyeweerd $(1963, \mathrm{p} 8)$.

44 Dooyeweerd (1963, p14-21).

45 Dooyeweerd (1963, p28-38).

46 Dooyeweerd (1963, p111-142).

47 Dooyeweerd (1963, p143-192).

48 Pico, 1486, Oratio de hominis dignitate. Vertaling: Rede over de menselijke waardigheid (2008, Historische Uitgeverij, Groningen, p50).

49 Ch. Taylor, 2007, A Secular Age, Harvard University Press, Cambridge, USA. Vertaling: Een seculier tijd (2009, Lemniscaat, Rotterdam).

5o H. Dooyeweerd, 1935-1936, De Wijsbegeerte der Wetsidee, Paris, Amsterdam.

51 Taylor (2009, p56, 252).

52 M. Callon, 1986, 'Some elements of a Sociology of Translation: Domestication of the Scallops and the Fisherman of St. Brieuc Bay' in J. Law (ed.), 1986, Power, Action, and Belief: A New Sociology of Knowledge?, Routledge and Kegan Paul, London en Latour (1994).

53 Recent werd het thema 'technologie en religie' door de Stichting Toekomstbeeld der Techniek aan de orde gesteld in de publicatie Deus et Machina. De verwevenheid van technologie en religie onder redactie van M. van Well (2008, STT, Den Haag).

54 In dit verband wil ik verwijzen naar de bijzonder interessante discussie tussen Luc Ferry en Marcel Gauchet of niet-heteronome vormen van absolute waarheden of immanente transcendentie als religieus geduid mogen worden. Ferry is van mening dat dit soort vormen als 'religieus' beschreven moet worden. Gauchet meent dat een profane manier van begrijpen ook mogelijk moet zijn. Zie L. Ferry et M. Gauchet, 2004, Le religieux après la religion, Grasset \& Fasquelle, Paris. Vertaling: Religie na de religie. Gesprekken over de toekomst van het religieuze (2008, Klement, Kampen). 
55 Borgman benadrukt het rituele karakter van techniek. Hij schrijft: 'Ik suggereer (...) dat er een ritueel aspect zit aan het gebruik van technologie en dat dit rituele aspect onlosmakelijk verbonden is met het menselijk "geloof" in technologie' (Van Well, 2008, p45).

56 Ferry in Ferry en Gauchet (2008, p72).

57 D. Noble, 1997, The Religion of Technology. The Divinity of Man and the Spirit of Invention, A.A. Knopf, New York.

58 H. Achterhuis, 2004, De gezondheidsutopie, Sobels, Utrecht.

59 Zie voor deze problematiek: H. Kunneman, 2005, Voorbij het dikkeik. Bouwstenen voor een kritisch humanisme, SWP, Amsterdam, M. van Hintum en J. Latten, 2007, Liefde à la carte. Trends in moderne relaties, Archipel, Antwerpen en M.J. Verkerk, 2008, Sterke vrouwen en mannelijke mannen. Een bijbelse visie op relaties en gezinsvorming, Sensor, Amersfoort.

6o HFDZKN, Speciale uitgave ter gelegenheid van het 6o-jarige bestaan van het Fonds Psychische Gezondheid (2009).

61 R. Kuiper, 2009, Moreel kapitaal. De verbindingskracht van de samenleving, Buijten \& Schipperheijn, Amsterdam.

62 R. Rotteveel e.a., 2002, Zorgprogramma's in de regio Heuvelland, Maastricht \& Westelijke Mijnstreek, Maastricht.

63 Uitzondering hierop vormde het zorgprogramma 'nieuwe patiënten'.

64 R. Atkinson, 1998, The Life Story Interview, Sage, London, p8.

65 J. Corbin and A. Strauss, 2008, 3rd ed., Basics of Qualitative Research. Techniques and Procedures for Developing Grounded Theory, Sage, London.

66 A. Maclntyre, 1981, After Virtue. A Study in Moral Theory, Duckworth, London.

67 Vollenhoven, 1943, Isagôgè Philosophiae. Opnieuw uitgegeven door Dordt College Press, Sioux Center, USA (2005). R. Mouw and S. Griffioen, 1993, Pluralisms and Horizons. An Essay in Christian Public Philosophy, Eerdmans, Grand Rapids.

68 H. Jochemsen en G. Glas, 1997, Verantwoord medisch handelen. Proeve van een christelijke medische ethiek, Buijten \& Schipperheijn, Amsterdam. M.J. Verkerk, J. Hoogland, J. van der Stoep en M.J. de Vries, 2007, Denken, ontwerpen, maken. Basisboek techniekfilosofie, Boom, Amsterdam.

69 Zie o.a. A. Faulkner, 2009, Medical Technology into Healthcare and Society. A Sociology of Devices, Innovation and Governance, Plagrave Macmillan, Hampshire. 
D.A. MacKenzie and J. Wajcman (eds), 1985, The Social Shaping of Technology: How the Refrigerator Got its Hum, Open University Press, Milton Keynes, Philadelphia. W.E. Bijker, T.P. Hughes, and T.J. Pinch, 1987, The Social Construction of Technological Systems: New Directions in the Sociology and History of Technology, MIT Press, London. W.E. Bijker, 1995, Of Bicycles, Bakelite, and Bulbs: Toward A Theory of Sociotechnical Change, MIT Press, London.

Callon (1986); B. Latour, 1987, Science in Action. How to Follow Scientists and Engineers through Society, Harvard University Press, Cambridge, MA; J. Law and J. Hassard (eds), 1999, Actor-Network Theory and After, Blackwell, Oxford.

72 S. Timmermans and M. Berg, 2003, 'The Practice of Medical Technology', Sociology of Health \& IIIness, 25 (Silver Anniversary Issue 2003), p97-114. S. Hyysalo, 2006, 'Representation of Use and PracticeBound Imaginaries in Automating the Safety of the Elderly', Social Studies of Science, 36 (4), p599-626.

73 J.F. den Hertog, R. Weehuizen and M.J. Verkerk, 2005, 'Process Innovation in Mental Health Care', MERIT, Maastricht.

74 Jochemsen en Glas (1997) en Verkerk e.a. (2007).

75 E. Borgman in Van Well (2008, p45).

76 Taylor stelt dat de buitensluiting of het irrelevant verklaren van religie vaak deel uitmaakt van de 'onopgemerkte achtergrond van de sociale wetenschap' (Taylor, 2009, p570). In de volgende artikelen en boeken wordt wel aandacht gegeven aan de invloed van religie: S.A. Buckler and K.A. Ziel, 1996, 'The Spirituality of Innovation: Learning from Stories', 13, P391-405; W.A. Stahl, 1999, God and the Chip. Religion and the Culture of Technology, Wilfrid Laurier University Press, Ontario ; Van Well (2008, p378-423) en N. Herzfield, 2009, Technology and Religion, Templeton Press, West Conshohocken.

77 Zie bijvoorbeeld S.D. Dodd and P.T. Seaman, 1998, 'Religion and Enterprise: An Introductory Exploration', Entrepreneurship: Theory \& Practice, Fall 1998, p71-86; I. Mitroff and E.A. Denton, 1999, 'A Study of Spirituality in the Workplace', Sloan Management Review, Summer 1999, p83-92; J. Marques, 2008, 'Spirituality at Work', The Journal for Quality and Participation, October, p24-27. Zie ook G. Broekstra e.a., 2006, De brug naar busi-ness spiritualiteit, Nieuwe Dimensies, Eemnes.

78 E. Borgman, 2008, '... want de plaats waarop je staat is heilige grond'. God als onderzoeksprogramma, Boom, Amsterdam. 
